\title{
COISA JULGADA E JUSTIÇA DAS DECISÕES ${ }^{1}$
}

\author{
Bruno Vasconcelos Carrilho Lopes \\ Mestrando em Direito Processual Civil na Faculdade de \\ Direito da Universidade de São Paulo. \\ Advogado em São Paulo.
}

\begin{abstract}
Resumo:
O instituto da coisa julgada, instrumento de efetivação do princípio da segurança jurídica, não pode ser interpretado isoladamente, sem atentar-se para outros princípios e garantias constitucionais, em especial a de acesso à ordem jurídica justa. A concepção de que a coisa julgada facit de nigro album et de albo nigrum cede ante situações nas quais haja séria violação à Constituição, com a imposição ao mundo da vida de uma situação absurda e incompreensível ao homem comum.
\end{abstract}

\begin{abstract}
:
The institute of the res juticata is an instrument in the act or rendering effective the principle of judicial safety; it can not be interpreted separately, without attention being paid to other constitutional principals and warranties, especially the access to fair judicial order. The idea that the res juticata facit de nigro album et de albo nigrum yield before situations where serious violations of the Constitution occur, with the imposition to the world of a life of an absurd and incomprehensible situation to the ordinary man.
\end{abstract}

Unitermos: Justiça; coisa julgada; segurança jurídica; princípios e garantias constitucionais; relativização da coisa julgada.

"Na vida da ciência - da ciência jurídica ou de qualquer outra - não há, nem pode haver, ponto de repouso definitivo. $O$ que antes se tiver virado do avesso pode sempre, a todo tempo, ser revirado: não no sentido de dar marcha à ré, de abrir mão do avanço consumado, de desprezar as recentes conquistas; mas no de averiguar se, com a ajuda das novas lentes, porventura não se obtêm, olhando noutra direção, quiçá no sentido contrário, imagens também novas e igualmente enriquecedoras"

(José Carlos Barbosa Moreira, A Justiça e nós, p. 3)

1. Trabalho vencedor do "Prêmio do Departaınento de Direito Processual" da Faculdade de Direito da Universidade de São Paulo no ano de 200l.E-mail para contato: bvl@dinamarco.com.br. 
1. Introdução.

Em 1904, ao discorrer sobre a coisa julgada, Giuseppe Chiovenda iniciou seu texto com estas palavras: "della cosa giudicata dirò poche cose ed assai brevemente; perchè sul vatissimo tema poco ormai resta a dire, che non sia inutile" (destaque nosso). ${ }^{2}$

O grande número de estudos desenvolvidos sobre esse instituto no decorrer do século passado demonstraram o erro de tal assertiva. Muitas foram as transformações no modo como a natureza, os limites subjetivos e objetivos da coisa julgada, entre outros aspectos, são interpretados pela doutrina e aplicados ao caso concreto.

$\mathrm{O}$ presente estudo, na esteira de recentes trabalhos doutrinários e manifestações da Jurisprudência, busca interpretar o instituto de modo sistemático, em consonância com os demais princípios e institutos integrantes do ordenamento jurídico pátrio, em especial com a garantia constitucional do acesso à ordem jurídica justa $(\mathrm{CF}$, art. $5^{\circ}$, inc. XXXV). ${ }^{3}$

Nessa linha, serão tecidas primeiramente algumas considerações acerca do conceito de Justiça e da sua aplicação ao caso concreto. Adiante, após uma análise dos elementos estruturais da coisa julgada e dos preconceitos da doutrina tradicional acerca de seu caráter absoluto, buscar-se-á conciliar a coisa julgada com os demais princípios fundamentais informadores de nosso sistema jurídico.

2. O Conceito de Justiça.

A eterna busca por um conceito de Justiça reflete o anseio dos juristas por um parâmetro, um "código doador de sentido" ${ }^{4}$ capaz de avaliar a legitimidade do Direito Positivo. Um sentido que permaneça firme perante a mutabilidade da ordem social e da vontade dos governantes. ${ }^{5}$

\section{Sulla cosa giudicata, p. 399.}

3. Tal expressão, já corrente nos estudos de direito processual, é atribuída a Kasuo Watanabe, cfr. Assistência judiciária e o juizado de pequenas causas, p. 161. Segundo Cândido Rangel Dinamarco, ela significa a "abertura de caminhos para obter sóluções justas para conflitos e eliminação de estados de insatisfação-justas porque conformes com os padrões éticos e sociais da nação" (Superior Tribunal de Justiça e acesso à ordem juridica justa, p. 251).

4. Cfr. Tércio Sampaio Ferraz Júnior, Introduçũo ao estudo do direito: técnica, decisão, dominação, p. 350.

5. Cfr. Tércio Sampalo Ferraz Júnior, Introdução ao estudo do direito: técnica, decisão, dominação, pp. 350-351. Em interessante ensaio acerca da gênese do sentimento de Justiça no ser humano, Tércıo SAMPAIO FerRaZ JúnIor considera-a, entre outros aspectos, como reflexo de um sentimento anterior, a inveja. Da inveja de um indivíduo em face da condição de outro emergiria a vontade de equiparação e, como decorrência, o sentimento de justiça. Cfr. Justiça como retribuição - da razão e da emoção na construção do conceito de justiça, pp. 385-389. 
A palavra justo remete a proporção, exata medida, harmonia, adequação. ${ }^{6}$ Nessa linha, é o conceito de Justiça fornecido pelo livro I, título I, das Institutas de Justiniano: "justiça é a vontade constante e perpétua de dar o seu direito a cada um" 7 Tal conceito é reafirmado no título I, parágrafo $3^{\circ}$ ao serem enunciados os preceitos jurídicos que devem informar a vida de todos os seres humanos: "viver honestamente, não ofender a outrem, dar a cada um o que é seu". "

$\mathrm{Na}$ História do conceito de Justiça, tal fórmula une-se à amplamente difundida concepção aristotélica. Para o filósofo grego, a Justiça pode ser vista sob duas perspectivas distintas, a Justiça comutativa, "que obedece relação absoluta, numérica ou aritmética" " e a Justiça distributiva, "de caráter corretivo, destinada a reger, proporcionalmente, as relações sociais em função do devido a cada um segundo seus méritos ou responsabilidades" "Essa última seria a Justiça das relações sociais, a Justiça do Direito, por meio da qual seria implementada a igualdade entre os seres humanos."

Não-obstante as inúmeras divergências entre as diversas teorias formuladas sobre o tema, as clássicas idéias do dar a cada um o que é seu (suum cuique tribuere), e do tratar os iguais na medida de suas desigualdades constituem cerne fixo de quase todas elas. A diferença básica entre os diversos conceitos de Justiça consiste no preenchimento do espaço deixado por essas fórmulas, nos parâmetros determinadores do que é o de cada um e na delimitação das desigualdades relevantes ${ }^{12}$. Nas palavras

6. Cfr. Goffredo Telles Júnior, A folha dobrada, p. 153. "La justicia lo mismo en un sentido restringido, que en una acepción lata -, es entendida casi siempre como una armonia, como una igualdad proporcional, como una medida armónica de cambio y de distribución" (LuIS RECASÉns SICHES, Estudios de filosofia del derecho, p. 385).

7. SPENCER VAmpré, Institutas do imperudor Justiniano, p. 3.

8. SPENCER VAMPRÉ, Institutas do imperador Justiniano, p. 4.

9. Miguel Reale, Nova fase do direito moderno, p. 10.

10. Miguel Reale, Nova fuse do direito moderno, p. 10. Como bem observado por Rui Barbosa, " $a$ regra da igualdade não coexiste senão em aquinhoar desigualmente aos desiguais, na medida em que se desigualam" (Oraşão aos moços, p. 418).

11. Cfr. Gustav RadBruch, Rechtsphilosophie, pp. 159-162.

12. "As discussões modernas sobre a justiça costumam encará-la sob dois aspectos que poderíamos classificar da seguinte maneira. No seu aspecto formal, ela aparece como um valor ético-social de proporcionalidade em conformidade com o qual, em situações bilaterais normativamente reguladas, se exige a atribuição a alguém daquilo que the é devido. Trata-se da idéia clássica do suum cuique tribuere, que reclama, porém, num segundo aspecto, a determinação daquilo que é devido a cada um. A conformidade ou não com critérios sobre o que e a quem é devido é o problema do aspecto material da justiça" (TÉrcio Sampalo Ferraz JúnIor, Introdução ao estudo do direito: técnica, decisão, dominação, p. 351). Para Luis Recaséns Siches, concep̧ões de Justiça alicerçadas nas fórmulas aventadas trazem 
de Luis Recaséns Siches: "el problema capital sobre la justicia no radica en la teoría de ella, sino el la medida de estimación que ella postula" 13

$\mathrm{Na}$ tentativa de enunciar critérios para resolver tal problema, Goffredo Telles Júnior concebe duas modalidades de Justiça, o justo por convenção, que "é aquilo que é tido como justo porque assim se convencionou" ${ }^{14}$ e o justo por natureza, que deflui da "simples natureza das coisas" 15 No entanto, à medida que essas concepções podem oferecer soluções distintas, de nada adianta traçar a diferenciação sem optar pela prevalência de alguma delas. Tal é o cerne da infindável disputa entre jusnaturalistas e positivistas, esses pregando a prevalência do justo por convenção, aqueles do justo por natureza.

No Brasil, país de tradição essencialmente positivista, um grupo de juízes, pertencentes na sua maioria à região sul do país, passou a apregoar que o justo por natureza deve prevalecer a qualquer custo, devendo-se desprezar a lei quando a solução nela contida revelar-se insatisfatória. A tal movimento, que deita raízes na Escola do Direito Livre, nascente na Alemanha no início do século passado, ${ }^{16}$ denominou-se Escola do Direito Alternativo. ${ }^{17}$

\footnotetext{
diferentes resultados porque "la mera idea de la igualdad o proporcionalidad no nos suministra el criterio" de medida, el principio para apreciar y promover esa armonía; esto es, no nos suministra el punto de vista desde el cual se deba atender a la igualación" (Estudios de filosofia del derecho, p. 387). Segundo Herbert L. A. Hart, "embora 'tratar da mesma maneira os casos semelhantes e diferentemente os casos diferentes' seja um elemento central na ideia de justiça, ele é em si mesmo incompleto e, até ser complementado, não permite nenhum guia determinado para a conduta. Tal sucede assim porque, em qualquer conjunto de seres humanos, eles assemelham-se entre si em alguns aspectos e diferem entre si noutros $e$, até que estejam estabelecidas que semelhanf̧as e que diferenças são relevantes 'tratar da mesma maneira os casos semelhantes' permanecerá uma fórmula vazia" (The concept of law, $\mathrm{pp}$. 173174). Por fim, para Miguel Reale, "o suum cuique tribuere, longe de ser uma solução, é antes um enunciado de problemas, pois fica sempre de pé saber o que é seu de cada um, em sua individualidade concreta; como é possivel atribuir algo a cada um sem se levar em conta o atribuivel proporcionalmente aos demais; e, finalmente, como é que a atribuiçäo pode e deve ser feita em razüo das circunstâncias ocorrentes. Cada um desses elementos não implica apenas distintos critérios formais, mas também 'variáveis conjunturais" dependentes de lugar e de tempo, duas coordenadas insuprimiveis da experiência" (Nova fase do direito moderno, p. 41).
}

13. Estudios de filosofia del derecho, p. 387.

14. A folha dobrada, p. 155.

15. A folha dobrada, p. 156. Quanto ao justo por natureza, como observa Goffredo Telles Júnior, problema maior que sua diferenciação do justo por convenção consiste em encontrar sua substância, aquilo que verdadeiramente constitui a essência das coisas: "como é difficil saber, muitas vezes, o que é seu verdudeiramente! O que sabemos, sim, com segurança, é o que é seu por convençāo" (A folla dobrada, p. 157).

16. Cfr. KarL LaRenz, Methodenlehre der Rechtswissenschaft, pp. 77-83.

17. Apesar de ter encontrado inúmeros adeptos pelo País afora, tal escola recebeu inúmeras críticas, dentre elas a de Goffredo Telles Júnior: "o poder nä̃o fundado na lei, o poder contra a lei, é o poder discricionário. É exatamente, o poder que odiamos, porque é o poder dos ditadores e dos tiranos. É o 
Em contrapartida, para Hans Kelsen, “o anseio por justiça é o eterno anseio do homem por felicidade" ${ }^{18}$ Como o alcance da felicidade pelos seres humanos não é proporcionado pelos mesmos bens da vida, a Justiça seria um valor relativo, dependente da concepção particular de cada indivíduo, o que impediria a construção de uma ordem social considerada justa por todos. ${ }^{19}$ Dentre os diversos valores que informam a conduta humana em busca da felicidade, alguns são eleitos pelo legislador como fundamentais. Tais valores são consubstanciados em normas jurídicas positivas, as quais, para o jurista austríaco, são o único parâmetro de que se dispõe para avaliar de modo objetivo e seguro a Justiça de um evento. ${ }^{21}$ Sob esse prisma, "o conceito de justiça transforma-se de princípio que garante a felicidade individual de todos em ordem social que protege determinados interesses, ou seja, aqueles que são reconhecidos como dignos dessa proteção pela maioria dos subordinados a essa ordem" ${ }^{21}$ Sendo o direito posto o parâmetro para a aferição do justo, a única solução injusta seria aquela que afastasse a aplicação do direito positivo.

$\mathrm{Na}$ obra de Gustav Radbruch encontra-se solução que, de certa forma, concilia as vertentes expostas. Segundo o célebre jurista alemão, o estabelecimento dos parâmetros substanciais do conceito de Justiça é realizado pelos princípios fundamentais que informam certa ordem social, os quais variarão de acordo com o momento histórico e com os fins a que a sociedade almeja alcançar. Em conjunto com as idéias de Justiça e de finalidade, diante da mutabilidade dos fins passíveis de serem eleitos, assoma a idéia de segurança, a qual, tendo como instrumento o direito positivo, estabiliza e torna objetivos os fins a serem perseguidos pela sociedade. Ou seja, a Justiça ganha um sentido concreto à medida que balizada por valores abarcados pelo Direito Positivo. Para Gustav Radbruch, essa seria a coordenação normal entre Justiça, fim e segurança. No entanto, tal sincronia não é absoluta. Em situações excepcionais, nas quais o respeito a essa ordem provoca grande ofensa a um desses prismas, especialmente nos casos de grave ofensa à Justiça, ela pode ser momentaneamente quebrada. ${ }^{22}$

poder que odiamos, mesmo quando esse poder esteja nus müos de juízes. Sim, é certo, situaçöes de injustiça social existem, por toda a parte. Enão há dávida que a justiça humana é imperfeita. Mas, ainda mais imperfeita e tornará, se ela for entregue ao arbitrio dos juizes" (A follha dobrada, p. 162).

18. Hans Kelsen, What is justice?, p. 2.

19. Hans Kelsen, What is justice?, pp. 2-5. Cfr., ainda, Hans Kelsen, Reine Rechtslehre, p. 39; EduaRdo García Máynez, Algunos aspectos de la doctrina kelseniana, p. 39.

20. HANS KeLSEN, What is justice?, pp. 3-4.

21. Hans Kelsen, What is justice?, p. 4.

22. Rechtsphilosophie, pp. 159-168. 
A partir do pensamento de Gustav Radbruch, no capítulo seguinte, ao se falar da Justiça aplicada ao caso concreto, expor-se-á uma proposta de balanceamento entre o justo por natureza e o justo por convenção.

\section{A Justiça aplicada ao Caso Concreto.}

Após ter violentado uma jovem donzela, um dos cavaleiros do rei Artur foi submetido ao julgamento da rainha e de suas damas. Elas resolveram poupar a vida do cavaleiro caso ele encontrasse no prazo de um ano e um dia a resposta para esta pergunta: "o que é que quase todas as mulheres mais desejam?" Passado um ano, chega o último dia e o cavaleiro dirige-se em direção ao castelo da rainha sem ter encontrado resposta alguma. No caminho, o cavaleiro defronta-se com "uma bruxa tão feia quanto a imáginação possa inventar", a qual, após saber do apuro em que o cavaleiro se encontra, diz conhecer a resposta para a questão, mas que apenas a revelará caso o cavaleiro dê sua palavra de que "seja qual for a coisa que eu vos peça em seguida, a fareis se estiver ao vosso alcance" Posto mais uma vez diante de duas alternativas (ser degolado a mando da rainha ou o desejo da bruxa, fosse qual fosse), $o$ cavaleiro escolhe a segunda, e fica então conhecendo o segredo: "quase todas as mulheres desejam ser soberanas e governar acima de seus maridos e impor o seu modo de amar" Satisfeitas a rainha e as damas da corte com a resposta, a bruxa exige do cavaleiro que ele case com ela. Na noite de núpcias, a bruxa volta a propor duas alternativas ao cavaleiro: "ou a aceita tão feia como é, e ela será uma esposa fiel e obediente toda a sua vida, ou transformar-se numa jovem e formosa donzela mas nunca lhe será fiel". Após ponderar algum tempo entre as duas alternativas, o cavaleiro não escolhe nem uma nem outra, mas se recusa a escolher. Nesse instante, a bruxa transforma-se numa bela jovem e também numa esposa fiel e obediente..$^{23}$

Tal é o dilema para o qual positivistas e jusnaturalistas ofertam soluções salomônicas. Diante da possível oposição entre a norma jurídica positiva e o justo por natureza, essas duas correntes filosóficas adotaram posicionamentos extremos. O ideal é a conciliação de ambos os valores. Diante de determinado caso concreto, não deve o juiz optar entre a beleza e a fidelidade, entre o justo e o direito positivo, seu dever é buscar nos lindes do Direito Positivo uma solução justa, aplicar o Direito Positivo com Justiça.

23. Cfr. Paul Watzlawick - Janet Helmick Beavin - Don D. Jackson, Pragmatics of human communication - A study of interactional patterns, pathologies, and paradoxes, pp. 209-210. 
Observemos a questão à luz da teoria de Hans Kelsen acerca da interpretação da norma jurídica. Para esse jurista, a norma pode ser vista como uma moldura, na qual podem ser enquadrados diversos posicionamentos, diferentes soluções para o caso concreto. Diante da natureza fundamentalmente relativa da Justiça, qualquer decisão que se encaixe na moldura seria conforme o Direito, sendo impossível demonstrar cientificamente ser outro o enquadramento justo, correto. ${ }^{24}$

A imagem da norma jurídica como uma moldura é interessante e de grande utilidade pois, diante (I) da linguagem não científica utilizada pelo legislador, ${ }^{25}$ (II) da existência de termos jurídicos de conteúdo indeterminado no seio do texto normativo, ${ }^{26}$ (III) da necessidade de recorrer-se ao senso comum, à ciência e à experiência pessoal e coletiva como fonte para a interpretação e aplicação das normas jurídicas, o reconhecimento do fatos relevantes para o deslinde da demanda ${ }^{27}$ e a correta motivação das decisões judiciais, ${ }^{28} \mathrm{e}$, principalmente, (Iv) do dever do juiz de interpretar as normas jurídicas sob os diversos prismas hermenêuticos (teleológico, sistemático, histórico e gramatical), o ordenamento jurídico, na grande maioria dos casos, expõe diferentes soluções para o caso concreto. Não-obstante, ao contrário do defendido por Hans Kelsen, nem todas as soluções encontradas no processo hermenêutico são satisfatórias. Como já observado, úma interpretação conjunta dos valores subjacentes ao Direito Natural e ao Direito Positivo implica considerar que, diante do caso concreto, deve o juiz buscar nas normas jurídicas, nos princípios constitucionais, no ordenamento jurídico como um todo, ${ }^{29}$ a solução que se revele mais justa. ${ }^{30}$

24. Reine Rechtslehre, pp. 465-467.

25. Conforme expõe Paulo de Barros Carvalho, enquanto o cientista do direito exprime-se em linguagem científica, precisa, o legislador exprime-se em linguagem técnica, com forte assento no discurso natural mas aproveitando diversos termos advindos da linguagem científica, cfr. Curso de direito tributário, pp. 4-8.

26. Acerca dos termos jurídicos indeterminados e de sua diferenciação dos atos discricionários, cfr. José Carlos Barbosa Moretra, Regras de experiencia e conceitos juridicamente indeterminados, pp. 605 622; José Roberto dos Santos Bedaque, Discricionariedade judicial, pp. 187-195: Eros Roberto Grau, $O$ direito posto e o direito pressuposto, pp. 141-166.

27. "A apreciação da prova está condicionada a um grau de subjetividade tão alto, que esta razão) por si só exclui toda possibilidade de calcular antecipadamente com certeza o resultado de casos em que existam fatos controvertidos" (Alf Ross, On law and justice, pp. 69-70).

28. Cfr. Michelle Tarufro, Senso comum, experiência e ciência no raciocínio do juiz, pp. 101-118.

29. O ordenamento jurídico é aplicado como um todo ao caso concreto, como uma totalidade sistematicamente estruturada dentro da qual deve se buscar a solução mais justa. Cfr. DAvid SCHNAID, A interpretução jurídica constitucional (e legal), p. 32-35.

30. "Uma coisa é o respeito à lei, devido por parte do juiz não menos que por parte de todos os membros da comunidade; outra, bem distinta, é o fetichismo do texto legal. Afigura-se bastante, em 


\section{O juiz não pode prostrar-se diante do caso concreto como uma máquina} insensível. ${ }^{31}$ Sua atividade desenvolve-se com o objetivo de pacificar com Justiça o conflito de interesses submetido a sua apreciação. ${ }^{32}$ Para tanto, não pode o julgador acomodar-se. Sob os influxos da lógica de lo razonable, ${ }^{33}$ o juiz moderno é desafiado

geral, o espaço deixado por este ao trabalho hermenêutico; e por via de interpretação não raro se chega a resultado suscetivel de comjugar em casamento harmomioso legalidade e justiģa. Atente o juiz, como é mister; no mandamento do art. $5^{\circ}$ da Lei de Introdufăono ao Código Civil; aplique a lei com os ollos postos nos fins sociais a que ela se dirige e nas exigências do bem comum - e o dilema, na esmagadora maioria dos casos, se mostrará mais aparente que real. Minha experiência pessoal de julgador; por quinze anos, no Tribunal de Justiģa de meu Estado, persuadiu-me de que, quando supunha defrontar-me com a angustiosa necessidade de escolher entre soluçäo injusta e solução ilegal, a raiz do problema quase nunca se situava na realidade, mas em meu próprio espírito: era eu que não estava sabendo dar à lei interpretafäo correta - nem, portanto, equaciomar devidamente a questäo. Refazendo os passos do raciocinio, não se tornava difícil, em regra, achar saída que me livrasse da terrivel opção" (José CARLos Barbosa Moreira, $O$ juiz e a cultura da transgressão, p. 260). "Entre duas interpretaf̧ões aceitáveis, deve pender por aquela que conduza a um resultado mais justo, ainda que aparentemente a vontade do legislador seja em sentido conträrio (a men.s legis nem sempre corresponde à mens legislatoris); deve 'pensar duas vezes antes de fazer uma injustiģa' e só mesno diante de um texto. absolutamente sem possibilidade de interpretą̧ão em prol da justiça é que deve comformar-se" (ANTÔNIO CARLOS DE ARAúso Cintra - Ada Pelegrini Grinover - Cándido Rangel Dinamarco, Teoria geral do processoo, p. 35). Cfr., ainda, Luis ReCaséns Siches, Tratudo general de fillosoffía del derecho, pp. 660-661; Cándido Rangel. Dinamarco, A instrumentalidade do processo, p. 161; David Schnaid, a imerpretaģão jurílica comstitucional (e legal), p. 30; HUMBERTO THEODORO JÚNIOR, Embargos à execus:ão comtra a fazenda píblica - extensão da matéria argiaível - princípios comstitucionais em conflito - proporcionalidade ou razoabilidade - coisa julgada e justa indenizaçäo-princípio de justiça e moralidade, pp. 122-124. Essas são as razões que levaram FranCESCo Carnelurtr considerar ser preferivel a um povo ter leis injustas e bons juízes do que maus juízes e leis justas. Cfr. LuIs ReCASÉns SiCHEs, Nueva filosofia de la interpretación del derecho, p. 130.

31. "La función valoradora no está reservada exclusivamente al legislador: Por el contrato, la función valoradora penetra, permea e impregna todos los grados en la producción del Derecho. La función del juez en este sentido, aun manteniéndose, como debe hacerlo, dentro de la obediencia al Derecho positivo válido y vigente, es siempre creadora; pues se alimenta de un rico complejo de valoraciones particulares sobre los puntos singulares" (LuIS RECASÉNS SICHES, Introducción al estudio del derecho, p. 260). "O magistrado não é amannense da lei, com mera função de conferir fatos com disposições legais, aplicando textos com a insensibilidade das máquinas. A própria lei confere funsũo singular ao magistrado, quando estabelece que, na sua aplicação, o juiz atenderá aos fins sociais è̀s exigências do bem commun. Em outras palavras, a lei deve ser; nas mãos de seu aplicador; um instrumento de realização do bem social, porque o rigorismo da interpretaģäo dos textos legais pode, muitas vezes, nos conduzir ao descompasso com a realidade, o que significaria o primeiro passo para uma injustiga" (STJ, $4^{a}$ Turma, Resp. n. 299/RJ, rel. Min. Sálvio de Figueiredo TeiXeira, j. 28.8.89, v.u., in Revista do Superior Tribunal de Justiça 4 (1989), p. I.559).

32. A atividade jurisdicional está submetida ao alcance de escopos jurídicos, políticos e sociais. Dentre eles destaca-se a pacificą̧̧ão com justiça, finalidade última para a qual deve o processo dirigir-se. Cfr. Cândido Rangel Dinamarco, A instrumentalidade do processo, pp. 159-162.

33. Tal é o método de raciocínio de grande utilidade proposto por LuIS RECASÉns SiChes. Eis sua características: (I) é profundamente influenciado pela realidade concreta do mundo em que opera; (II) está impregnado de valorações, de critérios axiológicos, os quais se referem a uma situação humana real, concreta, e constituem base de apoio para a formulação de fins para a atividade jurisdicional; (III) tais 
a assumir cada vez mais um papel ativo e criativo na interpretação da lei, adaptando-a, em nome da Justiça, aos princípios e valores de seu tempo. ${ }^{34}$

No limite dessas questões encontra-se a hipótese em que, após todo o labor hermenêutico do aplicador da lei, não foi possível encontrar amparo para a solução que no seu sentir é a mais justa. Nesse caso, diante da necessária busca de conciliação entre os valores segurança e Justiça, deve em regra, como última ratio, a decisão injusta mas conforme o direito prevalecer. ${ }^{35}$ No entanto, excepcionalmente, em hipóteses de

fins não se apóiam somente eın valorações, mas também nas possibilidades oferecidas pela realidade humana concreta; (IV) está regido por razões de adequação entre (a) a realídade social e os valores, (b) entre os valores e os fins, (c) entre os fins e a realidade social concreta, (d) entre os fins e os meios predispostos para o alcance desses fins, a adequação dos meios, sua correção ética e sua eficácia; (v) por fiın, a lógica de lo razonable está orientada pela experiência de vida humana e pela experiência histórica e se desenvolve instruída por essa experiência. Cfr. Introducción al estudio del derecho, pp. 258-259.

34. Cfr. Michelle Taruffo, Senso comum, experiência e ciência no raciocínio do juïz., p. 118. Ao analisar o caso concreto, deve o juiz ater-se aos interesses substanciais em jogo, sem se perder em conceitualismos. Tal é a tônica da jurisprudência dos interessess, em contraposição ao defasado e retrógrado prisma metodológico da jurisprudência dos conceitos. Cfr. KARL LARENZ, Methodenlehre der Rechtswissensschuft, pp. 63-77; CELSO LAFER, A reconstruf̧äo dos direitos humunos, pp. 57-58; JOSÉ DE Oliveira AsCENSÃo, O direito - introduşăo e teoria geral - uma perspectiva luso-brasileira, pp. 379-382; Miguel Reale, Revogaf̧ão e amulamento do ato administrativo, p.15.

35. "Toda vez que o magistrado se defronta com uma controvérsia, com um interesse resistido, deve idealizar a solusão mais justa para o caso concreto. Ele deve partir para a fixas:ão do desiderato, inicialmente, de acordo com a formas ão humanistica que possui e, somente após, já fixado a desideratos desejável para o caso, partir para a dogmática e, aí, tentar buscar; na dogmática, o apoio para a conclusãos "que che gou inicialmente. Encontrando esse apois, como quer o Direito, tona transhicido o Direito no provimento judicial. Não encontrando, ai sim, lamenta e conclui de forma diametralmente oposta ì soluçcio idecalizada" (STF, 2a Turma, Rext. n. 111.787/GO, rel. Min. Marco AuréLo De Mello, v.m., j. 16.4.91, in Revista trimestral de jurisprudência 136 (1991), p. 1295). "O juiz é um homem que se move dentro do direito como o prisioneiro dentro de sel carcere. Tem liberdade para mover-se e nisso atua sua vontade; o direito, entretanto, the fixa limites muito estreitos, que não podem ser ultrapassados. $O$ importante, o grave, o verdadeiramente transcendental do direito não está no cárcere, isto é, nos limites, mas no próprio homem" (Eduardo Juan Couture, Introdución al estudio del derecho procesal civil, p. 58). "Que o juiz. não se limita a utilizar normas pré-fabricadas, mas desempenha também aí uma função criadora, é coisa que ninguém mais duvida. O juiz simples 'boca da lei', sonhado por antiga doutrina, se alguma vez existiu, é defunto de longa data sepulado. Há limites, contudo, para semelhante criaģão. $O$ juiz cria nos intersticios da rede normativa; não se lhe permite sobrepor a ela sua fantasia, sorvida que seja nas fontes mais puras e alimentada pelas mais santas intenșós. Falece ao juiz. legitimaşão política para irrogar-se com amplitude o papel de legislador: Se, de acordo com a lei, al ou gual comportamemo é proibido, não compete ao juiz pôr de lado, sem mais aquela, a proibição, para conceder suas bênşãos a quem a infringiu. Errará se puser a decisão em termos estritamente relacionados com a espécie sub) judice; e mais gravemente errará se enunciar; à guisa de fundamenta̧̧ăo da sentença, princípio tendente a absolver aquilo que a lei condena" (José CARLOS B ARBosa MoReIRA, O juize a cultura da transgressáo, pp. 259-260). Cfr., ainda, Cândido Rangel Dinamarco, A instrumentalidade do processo, pp. 294-295; antônio Carlos de araújo Cintra - Ada Pelegrini Grinover - Cândido Rangel Dinamarco, Teoril geral do processo, p. 35; TJSP, $4^{2}$ Câmara Cível, Ap. n. 61.395-1, rel. Des. Alves BraGa, j. 3.10.85, v.u., in Revista dos Tribunais 604 ( 1986), p. 43; STF, I² Turma, Rext. n. 93.701-3/MG, rel. Min. OsCar CorrêA, j. 24.9.85, v.m., in Revista brasileira de direito processual 50 (1986), p. 168. 
grande injustiça, em que valores básicos e fundamentais dos seres humanos são violados, ${ }^{36}$ o respeito à segurança, ao Direito Positivo, perde o sentido, a relevância, devendo esse ser posto de lado e ser aplicada ao caso concreto a solução justa. ${ }^{37}$

No próximo capítulo discorrer-se-á sobre a coisa julgada e o modo como ela é tradicionalmente interpretada pela doutrina.

\section{A Coisa Julgada e a Segurança das Decisões Judiciais.}

Seguindo os passos de Enrico Tullio Liebman, a doutrina nacional majoritária afirma ser a coisa julgada material uma especial qualidade que incide sobre os efeitos substanciais das sentenças de mérito, tornando-os imutáveis; a imunização ${ }^{3 *}$ desses efeitos contra discussões futuras. ${ }^{39}$

36. É o caso dos direitos fundamentais da pessoa humana. Derivados de atributos inerentes à condição humana, tais diretos desenvolveram-se no decorrer da história tendo como fundamento "a consciência ética coletiva, a conviç̧ão, longa e largamente estabelecida na comunidade, de que a dignidade da condição humana exige o respeito a certos bens on valores em qualquer circunstância, ainda que não, reconhecidos no ordenamento estatal, ou em documentos normativos internacionais" (FÁBIO KondER Comparato, A afirmação histórica dos direitos humanos, p. 47). Caso a aplicação da lei ao caso concreto ofenda esses direitos, o direito positivo deve ser afastado, prevalecendo a solução justa.

37. Cfr. Karl Engisch, Einführung in das Juristische Denken, p. 320; Gustav Radbruch, Rechtsphilosophie, pp. 415-41.8. Como observa Tércio SAmpalo FerRaz JúnIOR: "de modo geral, a justiça, enquanto código das mensagens jurídicas e políticas, constitui uma espécie de razão de ordem superior, totalizadora e unificadora, e que confere um sentido näo adaptativo às mensagens. Enquanto normas jurídicas e regras políticas são mensagens que admitem adaptaçöes a mudanças ocorridas no universo das necessidades sociais (a lei muda, o programa politico muda, mudam os interesses), a justiça assegura uma espécie de resistência à mera mudança, posto que, entre todos os códigos, ela confere ao universo das ações humanas um sentido persistente e dominante. Embora o código da justiça não seja o único a codificia-las, é certo que nenhum homem pode sobreviver numa situaçäo em que a justiça, enquanto sentido unificador de seu universo, foi destruida, pois a carência de sentido torna a vida insuportável (diante de uma injustiga, on o homem sucumbe e perde sua dignidade, ou luta e se torna um revolucionário)" (Estudos de filosofia do direito - reflexĩes sobre o poder, a liberdade, a justiça eo" direito, p. 235).

38. Acerca do conceito de imunização, cfr. Tércio Sampaio Ferraz Júnıor, Teoria da norma jurídica: ensaio de pragmática da comunicação normativa, p. 106.

39. Cfr. Enrico Tullio Liebman, Efficacia ed autorità della sentenza, pp. 1-6; José Frederico Marques, Instituições de direito processual civil, v. V, p. 29; José RoberTo dos SANTOS BEDAQUe, Direito e processo - influência do direito material sobre o processo, pp. 96-101; CÁndido Rangel Dinamarco, Relativizar a coisa julgada material, pp. 12-13. Nas palavraș de Cândido Rangel Dinamarco: "caracterizada como um estado de segurança jurídica quanto às relaçöes entre os que litigaram no processo, a coisa julgada material incide sobre os efeitos da sentença de mérito e não é um efeito dela. Nos efeitos da sentença reside a fórmula de convivência não encontrada pelos sujeitos de modo amigável e pacífico, tanto que precisaram valer-se do processo e do exercício da jurisdição pelo Estado-juiz. A sentença estabelece essa fórmula, lançando-os para fora do processo e tendo uma natural tendência a impor-se na vida comum dos sujeitos. A coisa julgada é somente uma capa protetora que imuniza esses efeitos e protege- 
Ao lado da coisa julgada material, a doutrina identifica a coisa julgada formal, a qual determina a imutabilidade da sentença no âmbito do processo em que proferida, a impossibilidade de interposição de qualquer recurso contra a decisão que põe termo ao processo."

Para a presente investigação interessa a coisa julgada material. Tal instituto insere-se no ordenamento jurídico como um instrumento de efetivação do princípio da segurança jurídica. Não é conveniente à sociedade que as decisões judiciais sejam permanentemente instáveis, ${ }^{41}$ sendo necessário, em nome da segurança jurídica, definir um momento a partir do qual a sentença e os efeitos que ela projeta sobre o mundo da vida tornem-se imutáveis. ${ }^{42}$ É a coisa julgada um instituto de finalidade essencialmente prática, de utilidade social, destinado a "assegurar estabilidade à tutela jurisdicional dispensada pelo Estado" 43

os contra as neutralizaçōes que poderiam acontecer caso ela não existisse. Poderia o legislador vir a reger de modo diferente as relaçöes jurídico-materiais entre os sujeitos que litigaram, fazendo cair no nada o que o juiz decidira. Poderia o vencido desconsiderar o julgado, comportando-se de modo diferente ao que fora decidido, ou levantar novos fundamentos contra a decisão, tentando demolir a situação) criada ou declarada em sentença. E poderiam os juizes, quando provocados, rever as decisōes do próprio Poder Judiciário. Para que nada disso aconteģa e assim os efeitos da sentença resistam a todas essas possiveis pressĩes, é que a Constituição Federal garante a auctoritas rei judicatae e o Código de Processo Civil lhe dá disciplina técnico-processual. Não se trata de acrescer efeitos à sentença, portanto, mas de imunizar os que elas tem" (Instituições de direito processual civil, v. III, pp. 303-304). JosÉ CarLos Barbosa Moreira, na tentativa de aprimorar a concepção de Enrico Tullıo Liebman, defende que tal qualidade não incide sobre os efeitos da sentença, mais sim sobre o conteúdo dessa. Cfr. Ainda e sempre a coisa julgada, p. 142. Para uma crítica à concepção de José Carlos Barbosa Moreira, cfr. José Roberto dos Santos Bedaque, Direito e processo - influência do direito material sobre o processo, p. 98.

40. Cfr. José Carlos Barbosa Morejra, Ainda e sempre a coisa julgada, p. 142; Cândido Rangel Dinamarco, Relativizar a coisa julgada material, p. 13.

41. Para Cândido Rangel Dinamarco, a certeza decorrente do trânsito em julgado de uma decisão judicial é importante passo a ser percorrido rumo ao escopo primordial do processo, a pacificaçāo com justiça. Cfr. A instrumentalidade do processo, p. 162. A relevância do princípio da segurança jurídica foi ressaltada por Antônio de Sampaio Dória: "ter-se-á atingido o máximo em organisação política, quando for tão perfeita a segurança, que a todos pareça, como as chuvas que caem do céu, natural e espontânea" (Os direitos do homem, p. 572).

42. "A garantia constitucional e a disciplina legal da coisa julgada recebem legitimidade política $e$ social da capacidade, que têm, de conferir segurança às rela̧̧ões jurídicas atingidas pelos efeitos das sentenças" (CÂndido Rangel Dinamarco, Relativizar a coisa julgada material, p. 11).

43. José Carlos Barbosa Moreira, Ainda e sempre a coisa julgada, p. 135. Nas palavras de GiusePPE CHIOVENDA, "Sono ragioni d'opportunità, riguardi d'utilità sociale, che fanno porre un termine alla indagine giudiziaria, e trattare la sentenza come legge irrevocabile pel caso concreto" (Sulla cosa giudicata, p. 400). Nesse sentido, cfr., ainda, GIUSEPPE ChIOvENDA, Istituzioni di diritto processuale civile, p. 370; JosÉ FrEDERICO Marques, Instituif̧ões de direito processual civil, v. V, p. 37; EduARdo JuAn Couture, Fundamentos del derecho procesal civil, p. 407; EnRICo Tullı LIEBMAN, Efficacia ed autorità della sentenza, p. 39; JosÉ Roberto dos Santos Bedaque, Direito e processo-influência do direito material sobre o proces.so, pp. 97 - 
Por se tratar de uma qualidade dos efeitos da sentença, a extensão e conformação da coisa julgada material sofre profunda influência da situação de direito substancial sobre a qual ela incide. ${ }^{44}$ Essa é a razão pela qual José Roberto dos Santos Bedaque indica situar-se tal instituto nos limites divisórios entre o direito processual c o material. ${ }^{45}$

Diante da suprema importância dada à segurança jurídica pela doutrina em geral, a coisa julgada é e sempre foi sacralizada. Conforme entendimento até pouco tempo atrás pacífico na doutrina e na Jurisprudência, entende-se que após a imunização da situação de direito substancial pela coisa julgada material, passado o prazo para a propositura de ação rescisória, a imutabilidade persiste independentemente da gravidade do vício acobertado pela coisa julgada (Res judicata facit de nigro album et de albo nigrum). Nessa linha, Eduardo Juan Couture faz menção ao famoso dístico de Scassia: "la cosa juzgada hace de lo branco, negro; origina y crea las cosas; transforma lo cuadrado en redondo; altera os lazos de la sangre y cambia lo falso en verdadero". ${ }^{4}$

No capítulo seguinte, analisar-se-á a interpretação tradicional da coisa julgada em face dos princípios informadores do processo civil moderno, do processo civil de resultados, do escopo de decidir-se de modo justo e équo o conflito de interesses deduzido perante o Poder Judiciário.

98; Willis Santiago Guerra Filho, Reflexĩes a respeito da mulureza da coisa julgada como problema filosífico, pp. 244-249. Conforme bem observado por W ALTER J. HABSCHEID, contrariando a concepção de JamEs GoldSChmidT, a coisa julgada não é o "fim último do processo civil". Os escopos do processo (sociais, políticos e jurídicos) são munidos de substância, de conteúdo material, e desse modo fornecem pautas de ação para o jurista. A coisa julgada é unicamente o meio técnico de fazer respeitar uma decisão em outro processo. Cfr. WALTER J. HABSCHEID, As bases do direito processual civil, p. 122.

44. "A coisa julgada não tem dimensões próprias, mas as dimensões que tivereın os efeitos da sentença" (Cândido Rangel Dinamarco, Intervenção de terceiros, p. I3).

45. Cfr. Direito e processo - influência do direito matevial sobre o processo, p. 93. A coisa julgada é um instituto bifronte, uma das "pomtes de passagem entre o direito e o processo, ou seja, entre o plano substancial e o processual do ordenamento jurídico" (Cándido Rangel Dinamarco, Instituişões de direito) processual civil, v. I, p. 44). Contrariando esse posicionamento alude José Frederico Marques que "a coisa julgada material é instituto de direito processual. Ela torna imutável a vontade concreta da lei que promana da sentença, criando, assim, vínculos de ordem puramente processual que impedem reexame do mérito da questão decidida por qualquer outro órgão investido do poder jurisdicional" (ln.stituições de direito processual civil, v. V, p. 46).

46. Fundamentos del derecho procesal civil, p. 405. Alcides Mendonça Lima expressa beın esse pondo de vista: "justa, ou injusta, legal ou ilegal, a sentença, de mérito, que se tornou res judicata, é intocável" (O processo como garantia das instituiģöes sociais, p. 151). 


\section{A Coisa Julgada e a Justiça das Decisões.}

Nos ordenamentos jurídicos modernos, a tarefa de delinear os princípios fundamentais que informam a ordem jurídica como um todo é conferida à Constituição. ${ }^{47}$ É nessa sede que estão enunciados os valores eleitos pela sociedade como fundamentais, os princípios que objetivamente dimensionarão o justo. Tais princípios, uma vez insertos na constituição, transformam-se na "chave de todo o sistema normativo" 48 Eles configuram o modo de ser de todo o sistema jurídico, determinando o viés a ser seguido pelo intérprete na tomada de decisões ${ }^{49}$

Como a ordem jurídica é formada de modo lento e gradual, encontrandose na evolução histórica influência de correntes axiológicas diversas e conflitantes, os princípios básicos do ordenamento jurídico podem entrar em conflito quando analisados perante uma situação concreta ${ }^{50}$

Sendo da essência dos princípios que eles entrem freqüentemente em conflito entre si, cumpre ao intérprete "encontrar um compromisso, pelo qual se destine, a cada princípio, um determinado âmbito de aplicação" Di Diante do conflito entre princípios, não se deve de modo algum tentar eliminar algum deles. A missão do intérprete é buscar uma solução conciliadora, definir a área de atuação de cada um dos princípios $^{52}$

47. Cfr. KonRad HesSe, Die normative Kraft der Verfassung, p. 21.

48. Paulo Bonavides, Curso de direito constitucional, p. 231.

49. "O intérprete ao realizar a sua função deve sempre iniciá-la pelos princípios constitucionais, é dizer, deve-se sempre partir do princípio maior que rege a matéria em questão, voltando-se em seguida para o mais genérico, depois o mais específico, até encontrar-se a regra concreta que vai orientar a espécie" (CELSO BASTOS, As modernas formas de interpretaçäo constitucional, p. 45).

50. Cfr. KaRL ENGisch, Einführung in das Juristische Denken, pp. 318-319. Tal fenômeno ocorre com frequêencia pois os princípios não disciplinam cada um deles uma situação isolada. Diversos princípios de vertentes axiológicas distintas exercem influência sobre um mesmo caso concreto. Como adverte Carlos Maximiliano: "não se encontra um princípio isolado em ciência alguma; acha-se cada um em conexão íntima com outros. O Direito objetivo não é un conglomerado caótico de preceitos; constitui vasta uzidade, organismo regular, sistema, conjunto harmônico de normas coordenadas, em interdependência metódica, embora fixada cada uma em seu lugar próprio. De princípios jurídicos mais ou menos gerais deduzem comlários; uns e outros se condicioname restringem reciprocamente, embora se desenvolvam de modo que constituem elementos autônomos operando em campos diversos" (Hermenêtica e aplicação do direito, p. 128).

51. Claus-Wilhelm Canaris, Systemdenken und Systembegriff in der Jurisprudenz, p. 205.

52. Claus-Wilhelm Canaris, Systemdenken und Systembegriff in der Jurisprudenz, p. 206. Em interessante análise sobre a questão, Robert Alexy considera que o jurista deve realizar uma ponderação entre os diversos princípios constitucionais em busca da solução mais justa, cfr. Colisão de direitos fundamentais e realização de direitos fundamentais no estado de direito, pp. 67-79. 
Nessa ordem de idéias, Paulo Bonavides aduz não haver uma única solução para o conflito entre princípios jurídicos. Prevalecerá sempre aquele que, especificamente no caso concreto, tiver maior força ${ }^{53}$ Tal prevalência não implica restrição em abstrato da força impositiva do princípio afastado. Em outras circunstâncias, diante de novos fatores relevantes, o princípio antes afastado está pronto para ser aplicado $^{54}$

Exemplo típico dessa oposição são as hipóteses de choque entre os princípios da Justiça e da segurança jurídica ${ }^{55}$. No processo, exige-se que tais princípios sejam coordenados com vistas ao alcance de seu escopo magno: a pacificação social com Justiça, o acesso à ordem jurídica justa.

Para atingir esse escopo, equilibrando as exigências de Justiça e segurança, deve o jurista concentrar-se nos resultados a serem alcançados mediante o processo $^{56}$. O processo não se esgota nas suas formas, no culto ao procedimento como um fim em si mesmo ${ }^{57}$ O processo é um instrumento de tutela do direito justo, e a interpretação dos princípios que o informam deve ser realizada em conformidade com essa perspectiva. ${ }^{58}$ Nesse sentido, a observação de Eduardo Juan Couture: "todos

53. Cfr. Paulo Bonavides, Curso de direito constitucional, p. 25I; Niklas Luhmann, Rechtssoziologie, v. l, pp. 103-104.

54. No mesmo sentido dessa análise, acerca dos princípios e da possível oposição entre eles, cfr. PAULo Henrique dos Santos Lucon, Garantia do tratamento paritário dás partes, p. 92-95.

55. Nas palavras de Karl Engisch: "a justiça exige uma grande 'concretizaşāo', quer dizer, uma consideração das circunstâncias individuais da pessoa e da situạ̧ão. A segurança jurídica, pelo contrário, exige uma grande abstração destas circunstâncias, tal como, designadamente, precisos limites de idade, prazos determinados, tarifas exactas" (Einführung in das Juristische Denken, pp. 319-320).

56. Tal é a tônica do processo civil de resultados, cfr. José Roberto dos Santos Bedaque, Direito $e$ processo - influência do direito material sobre o processo, pp. 15-16.

57. "As formas são necessárias, mas o formalismo é uma deformação" (ENRICo TulLIo LIEBMAN, Manuale di diritto processuale civile, v. 1, p. 258).

58. "Fala-se muito em interesse público na preservação do rito, do due process of law, como um valor absoluto e abstrato, para justificar as devastą̧̄oses concretas que a injustif̧a de um decreto de nulidade, de uma falsa preclusão, da frieza de um presunção processual desumana, causam à parte inerme. Não. Não é isto fazer justiça. Não é para isso que existe o processo. Esquecem os que assim pensam e agem, que os valores e os interesses no mundo do direito não pairam isolados no universo das abstraçöes; antes, atuam, no dinamismo e na dialética do real, em permanente conflito com outros valores e interesses. Certa, sem dúvida, a presença de interesse público na determinaçăo do rito. Mas, acima dele, se ergue outro, também público, de maior relevância: o de que o processo sirva, como instrumento, à justiça humana e concreta, a que se reduz, na verdade, sua única e fundamental razão de ser" (GALENO LACERDA, O código e of formalismo processual, p. 10). Analisando a questão sob a perspectiva do substantive due process of law, Luigi Paolo Comoglio tece estas considerações: "impone di considerare come dovuto (e cioè: come due, devido o devido) non già qualunque processo che si limiti ad essere estrinsecamente 
estamos habituados a manejar as formas do processo, seus prazos, suas condições, como se fossem fins em si mesmos. Esse ramo do direito, pois, nos surge, em sua aparência, como a forma solene, como o cerimonial da Justiça. A experiência, contudo, nos ensina que isso é unicamente o invólucro do fenômeno. Por debaixo da formas existe um conteúdo profundo e angustioso, que necessita aflorar à superfície". 5y

Ora, como já esboçado no item anterior, enquanto instrumento de efetivação do princípio da segurança jurídica, a coisa julgada é instituto fundamental para assegurar a pacificação social com Justiça, o efetivo acesso à ordem jurídica justa. Essa, no entanto, é apenas uma face da questão. Outros princípios têm grande importância para o alcance dos escopos do processo e da ordem jurídica como um todo. Diante do conflito entre o princípio da segurança jurídica e outros princípios de grande relevância, é necessário analisar, de acordo com as particularidades do caso concreto, ${ }^{(1)}$ qual princípio tem maior importância para a concretização desses escopos. ${ }^{61}$ Nas palavras de Cândido Rangel Dinamarco: "nenhum princípio ético ou político tem valor absoluto no universo dos valores e atividades de uma nação ou da própria Humanidade, nem valor suficiente para impor-se invariavelmente sobre outros principios e sobre todas as legítimas necessidades de uma convivência bem organizada. $O$ culto exagerado a determinado principio ou idéia fundamental resolve-se em fetichismo e presta-se a aniquilar outros principios ou idéias fundamentais de igual ou

\footnotetext{
fair (vale a dire: corretto, leale o regolare, sul piano formale, secondo la law of the land), bensi un processo che sia intrinsecamente equo e giusto, secondo i parametri etico-morali accettati dal comune sentimento degli uomini liberi di qualsiasi epoca paese, in quanto si riveli capace di realizzare una giustizia veramente imparziale, fondada sulla natura e sulla ragione. Da qui traggono origine le postulazioni teoriche, ormai quasi dovunque condivise, per la promulgazione e l'adozione di solenni atti legislativi (nazionali od internazionali) che riconoscano a tutti, in termini effetivi e senza irrazionali discriminazioni, il diritto fondamentale ad un processo equo e giusto, quale nucleo essenciale del più ampio diritto ad un ordinamento giuridico giusto" (Garanzie costituzionali e 'giusto processo' - modelli a comfronto, p. 105-106). Cfr., ainda, Antônio Carlos de Araúuo Cintra - Ada Pelegrini Grinover Cândido Rangel Dinamarco, Teoria geral do processo, pp. 41-42.
}

59. Introdución al estudio del derecho procesal civil, p. 3.

60. "A veces, la urgencia de seguridad choca com el deseo de una mejor justicia. Tales conflictos entre seguridad y justicia se resuelven según las características del caso concreto, unas veces en favor de la se guridad y otras veces sacrificando ésta en aras de la justicia" (LuIs RECASÉns SICHES, Nueva filosofia de la interpretación del derecho, p. 294).

6I. Conforme exposto por Luis Recaséns Siches: "la seguridad, si bien es el valor funcional del Derecho, aquel valor que todo Derecho trata de cumplir por el mero hecho de su existencia, no es de modo alguno el valor supremo en el que el Derecho debe inspirarse; pues resulta evidente que los valores más altos hacia los que el Derecho debe tender son la justicia, y el séquito de valores por ésta implicados, tales como la dignidad y la libertad de la persona humana, el bienestar social, etcétera" (Nueva filosofía de la imterpretación del derecho, p. 293). 
até maior relevância científica ou social, a dano de valores que clamam por zelo e preservação", 62

Nesse sentido, sensibilizados com uma interpretação integral dos princípios informadores do ordenamento jurídico, juristas de renome vêm propondo a relativização da coisa julgada. Tal instituto não pode ser interpretado de modo extremado, transformar o branco em preto e a mentira em verdade. A coisa julgada "deve ser posta em equilibrio com as demais garantias constitucionais e com os institutos jurídicos conducentes à produção de resultados justos mediante as atividades inerentes ao processo civil" "i. Isso porque "o valor segurança das relações jurídicas não é absoluto no sistema, nem o é a garantia da coisa julgada, porque ambos devem conviver com outro valor de primeiríssima grandeza, que é o da Justiça das decisões judiciárias, constitucionalmente prometido mediante a garantia do acesso à Justiça (Const., art. $5^{\circ}$, inc. XXXV)" ${ }^{64}$

62. Súmulas vinculantes, p. 52. "Os princípios existem para servir à justiça e ao homem, não para serem servidos como fetiches da ordem processual" (CÂndido Rangel Dinamarco, Instituiç̄öes de direito processual civil, v. I, p. 249). "Os grande princípios constitucionais do processo são en si mesmo perenes mas nem por isso devem ser cultuados como fetiches, nem sua leitura há de ser estanque no tempo" (CÂndido Rangel Dinamarco, Aceleração dos procedimentos, p. 905). "Muitos dos princípios processucuis, por exemplo, se levados às últimas conseqüências, sem considerar a realidade fática sobre que irão incidir, podem tornar-se verdadeiros óbices aos escopos do processo. Necesscírio, pois, 'relativizá-los', isto é, considerar os princípios processuais sempre como meios para obtenção de uma justiça rápida e eficiente. Sua aplicação jamais pode desconsiderar o litígio, sob pena de se construir um modelo processual inadequado ao seu objeto" (José RoBERTo dos SANTOS BEDAQUE, Direito e processo - influência do direito material sobre o processo, p. 50). "O nosso Direito atual, é infenso ao superado fetichismo de regras processuais que pudessem consagrar a injustiça, a imoralidade e a ilegalidade, contra a evidência dos fatos e com a execrável prevalência de uma verdade meramente formal, diante da inocultável verdade material, única com a qual o ideal de justiça, insito na garantia do due process of law, se acha comprometido (CF, art, $5^{\circ}$, LIV)" (HUMBERTO THEODORO JúNIOR, Embargos à execução contra a fazenda pública - extensãoo da matéria argüível - princípios constitucionais em conflito - proporcionalidade ou razoabilidade coisa julgada e justa indenização - princípio de justiça e moralidade, p.134).

63. Cândido Rangel Dinamarco, Relativizar a coisa julgada material, p. 12.

64. Cândido Rangel. Dinamarco, Relativizar a coisa julgada material, p. 14. Nesse ensaio encontrase uıma ininuciosa análise do posicionamento de doutrina e jurisprudência sobre a questão, incluindo as lições de Humberto Theodoro Júnior, Hugo Nigro Mazzili, Francisco Cavalcanti Pontes de Miranda, José Augusto Delgado, Eduardo Juan Couture, Juan Carlos Hitters, Jorge Miranda, Ada Pellegrini Grinover, da Jurisprudência do Supremo Tribunal Federal e da Jurisprudência e doutrina norte-americana. Luís Eulálio de Bueno Vidigal, após analisar as razões de conveniência prática da coisa julgada, ressalva que "em certos casos, entretanto, a natureza do vício causador da injustiça é de tal ordem, que apresenta inconveniente maior do que o da instabilidade do julgado" (Da ação rescisória dos julgados, p. 16). Cfr., ainda, Celso Bastos - Ives Gandra da Silva Martins, Comentários à Constituição do Brasil, v. 2 , p. 201-202; Óscar. A. Zorzolı, Cosa juzgada-mutabilidad,pp. I50-155; Francisco Barros Dias, Breve análise sobre a coisa julgada inconstitucional, pp. 34-42. Em meados do século passado, Eduardo Juan Couture já se indignava com certas situações que a coisa julgada poderia provocar: "la necesidad de firmeza debe ceder, en determinadas condiciones, ante la necesidad de que triunfe la verdad. La cosa 
Na esteira do pensamento de Gustav Radbruch, cumpre ressaltar que a concepção da coisa julgada como um valor absoluto pode contrariar até mesmo o próprio princípio da segurança jurídica. A primeira e mais substancial instância em que esse princípio ganha concretização é na criação do Direito Positivo. À medida que a decisão imunizada pela auctoritas rei judicata contrarie de modo frontal e indiscutível disposições do direito positivo, a coisa julgada, instrumento de efetivação do princípio da segurança jurídica no processo, estaria atentando contra esse mesmo princípio. ${ }^{65}$

Contra o posicionamento acima exposto, poder-se-ia objetar que o processo civil contenta-se com a verdade formal, cabendo unicamente ao processo penal a busca da verdade real. Ora, "dizer que o processo penal persegue a chamada 'verdade real', ao passo que o processo civil se satisfaz com a denominada 'verdade formal' é repetir qual papagaio tolicesmil vezes desmentidas" ". "Se por um pensamento superficial costuma-se dizer que as decisões do processo civil afetam unicamente o patrimônio, enquanto as do processo penal afetam a liberdade pessoal, uma análise mais atenta mostra "que no âmbito civil se trata com freqüência de problemas relativos a aspectos intimos e relevantíssimos da vida das pessoas, como ocorre, por exemplo, nos assuntos de família; e também no processo penal pode igualmente estar em jogo apenas o patrimônio, como acontece quando a infração não é punivel senão com multa" ${ }^{67}$

\begin{abstract}
juzgada no es de razón natural. Antes bien, la razón natural parecería aconsejar lo contrario: que el escrúpulo de verdad sea más fuerte que el escrúpulo de certeza; y que siempre, en presencia de una nueva prueba o de un novo hecho fundamental antes desconocido, pudiera recorrerse de nuevo el camino andado para restabelecer el imperio de la justicia" (Fundamentos del derecho procesal civil, p. 406). Ein recente trabalho, José Augusto Delgado ressalta que "a grave injustiça não deve prevalecer em época nenhuma, mesmo protegida pelo manto da coisa julgada, em un regime democrático, porque ela afronta a soberania da proteção da cidadania" (Pontos polêmicos das ações de indenização de áreas naturais protegidas efeitos da coisa julgada e os princípios constitucionais, p. 20). Por fim, Hugo de Brito Machado, analisando a questão da oposição entre a coisa julgada e outros princípios constitucionais de maior relevância, conclui que "se um dispositivo da própria constituiçăo alcança situaçăo objeto da coisa julgada, a garantia constitucional estará excepcionalmente afastada" (Direito adquirido e coisa julgada como garantias constitucionais, p. 22). Cfr., no mesmo sentido, STF, $1^{\text {a }}$ T., Rext. n. 140.894-4, rel. Min. llmar Galvão, v.u., j. 10.5.96, DJU 9.8.96, p. 27.102. Em sentido contrário, abordando exclusivamente a questão da reforma constitucional, José Afonso da Silva considera não ser possível qualquer limitação aos princípios do direito adquirido, do ato jurídico perfeito e da coisa julgada por uma emenda à Constituição. Cfr. Poder constituinte e poder popular - estudos sobre a Constituição, pp. 221-233.
\end{abstract}

65. Rechtsphilosophie, pp. 345-346.

66. José Carlos Barbosa Moreira, a Constituiģăo e ais provas ilicitamente obtidas, p. 118.

67. José Carlos Barbosa Moreira, A Constituiģão e as provas ilicitamente obtidas, p. 118. No mesmo sentido, a advertência de Antônio Carlos de Araújo Cintra - Ada Pelegrini Grinover - Cândido Rangel Dinamarco: "quando a causa não-penal versa sobre relações juridicas em que o interesse público prevalece sobre o privado, não há concessĩes à verdade formal" (Teoria Geral do Processo, p. 65). 
Em suma, quando, no caso concreto, a coisa julgada viole princípio fundamental inserido na Constituição Federal que possua maior relevância para o alcance dos escopos do processo e da ordem jurídica como um todo, estaremos diante de uma coisa julgada inconstitucional, ${ }^{68}$ devendo o Poder Judiciário declará-la ineficaz quando provocado.

Nessas hipóteses, ao contrário do identificado pela maioria da doutrina que analisou a questão, há a formação normal da coisa julgada. A coisa julgada material opera toda vez que a sentença traga pronunciamento acerca do mérito da demanda, que a sentença se destine a produzir efeitos substanciais. No entanto, como dito anteriormente, diante da oposição entre a coisa julgada e algum outro princípio de maior relevância no caso concreto, a coisa julgada pode não prevalecer, ser ineficaz. ${ }^{69}$

Expostas essas premissas, no capítulo seguinte abordaremos os princípios constitucionais que vem sendo considerados pela doutrina e Jurisprudência como ensejadores da relativização da coisa julgada.

68. Em obra pioneira sobre o tema, Otto Bachof delineou a possibilidade da existência de normas constitucionais inconstitucionais, à ınedida que seja ofendido princípio fundamental de uma constituição. Cfr. Verfassungswidrige Verfassungsnormem?, pp. 54-59. Cfr., ainda, CÂndido Rangel Dinamarco, Relativizar a coisa julgada material, p. 25; FRANCISCO BARROs DIAS, Breve análise sobre a coisa julgada inconstitucional, pp. 40-41.

69. Partindo da premissa adotada por esse estudo, de que a coisa julgada não é um valor absoluto, existindo outros valores fundamentais que se sobrepõe a esse instituto, os autores que se propuseram a analisar a questão optaram por ditar a solução, talvez equivocada, de que a coisa julgada não incidiria sobre a disposição de mérito da sentença quando ela atentasse contra princípios fundamentais que possuam Inaior relevância no caso concerto: "onde quer que se tenha uma decisĩo aberrante de valores, princípios, garantias ou normas superiores, ali ter-se-ão efeitos juridicamente impossiveis e portanto näo incidirci a autoridade da coisa julgada material - porque, como sempre, não se concebe imunizar efeitos cuja efetivação agrida a ordem juridica constitucional" (CÁndido Rangel Dinamarco, Relativizar a coisa julgada material, p. 27). "O Texto Constitucional assegura a coisa julgada contra atentados que possa sofrer, inclusive provindos da própria lei. Mas ela nāo afirma que toda decisão com trânsiô em julgado constitui coisa julgada. Isto faz comn que necessariamente caiba à lei, à doutrina e à própria jurisprudência o dirimirem em cada caso concreto se há ou não coisa julgada" (Celso Bastos - Ives GandRa da Silva Martins, Comentários à Constituição do Brasil, $2^{\circ}$ v., p. 201). "A injustiça, a imoralidade, o ataque à Constituiçäo, a transformaçäo da realidade das coisas quando presentes na sentença viciam a vontade jurisdicional de modo absoluto, pelo que, em época alguma, ela transita em julgado" (José Augusto Delgado, Pontos polêmicos das açöes de indenização de áreas naturais protegidas - efeitos da coisa julgada e os princípios constitucionais, p. 20). Cfr., no mesmo sentido, Francisco Barros Dias, Breve análise sobre a coisa julgada inconstitucional, p. 4 I; Belmiro Pedro Wetter, Coisa julgada na investigação de paternidade, pp. 23-25. Ora, se a proposta é de relativização da coisa julgada material, o foco da questão não pode ser alterado para os efeitos substanciais da decisão imunizada, deterıninando-se que nos casos em que os efeitos atentem contra princípios fundamentais não opere a coisa julgada. Sempre que a decisão que põe fim ao processo decidir acerca do mérito da demanda, a coisa julgada incidirá. No entanto, nos termos do exposto neste texto, diante da colisão entre a coisa julgada formada e outros princípios constitucionais fundamentais, a coisa julgada pode não prevalecer no caso concreto. 


\section{Princípios Constitucionais determinadores da Relativização da Coisa Julgada.}

Mediante a consciência de que "a ordem constitucional não tolera que se eternizem injustiças a pretexto de não eternizar litígios", ${ }^{70}$ doutrina e Jurisprudência identificaram alguns princípios que podem prevalecer no caso concreto em face da coisa julgada material.

Tais são os princípios da proporcionalidade (ou razoabilidade), ${ }^{71}$ da democracia, ${ }^{72}$ da hierarquia das normas, ${ }^{73}$ da legalidade, ${ }^{74}$ da isonomia, ${ }^{75}$ da separação de poderes, ${ }^{76}$ da moralidade pública, ${ }^{77}$ da dignidade da pessoa

70. CÁndido Rangel Dinamarco, Relativizar a coisa julgada material, p. 31 .

71. HuMBERTO THEODORO JÚNIOR, Embargos à execuçāo contra a fazenda pública-extensão da matéria argüivel-principios constitucionais em conflito - proporcionalidade ou razoabilidade - coisa julgada e justa indenização-princípio de justiça e moralidade, pp. 133-135; CÂnDIDO RANGEL Dınamarco, Relativizar a coisa julgada material, p. 2 F; Paulo Henrique dos Santos Lucon, Devido processo legal substancial, cap. 4, n. i, letra d. Nos termos de manifestação do Min. José Carlos Moreira Alves, o princípio da proporcionalidade possui assento na ordem constitucional brasileira no principio do due process of law (CF, art. 5o, inc. LIV). Cfr. STF, ADIN n. 966-4, rel. Min. MARCo Aurél.o DE Mello, v.m., j. 11.5.94.

72. Cfr. Francisco Barros Dias, Breve análise sobre a coisa julgada inconstitucional, pp. 36-37.

73. Cfr. Francisco Barros Dias, Breve anailise sobre a coisa julgada inconstitucional, p. 36.

74. Cfr. Francisco Barros Dias, Breve análise sobie a coisa julgada inconstitucional, pp. 37-38.

75. Cfr. Francisco Barros Dias, Breve ancilise sobre a coisa julgada inconstitucional, p. 38; Hugo DE BRITo MACHADO, Direito adquirido e coisa julgada como garantias constitucionais, pp. 24-26.

76. Cfr. Francisco Barros Dias, Breve análise sobre a coisa julgada inconstitucional, p. 38.

77. “Ressalto, nesta oportunidade, a minha posiçāo doutrinária no sentido de não reconhecer caráter absoluto à coisa julgada material. Filio-me, a respeito, à determinada corrente que entende ser impossivel a coisa julgada, só pelo fundamento de impor segurança jurídica, sobrepor-se aos princípios da moralidade pública e da razoabilidade nas obrigaçōes indenizatórias assumidas pelo Estado. Esse meu posicionamento nāo nega a proteção do direito subjetivo de qualquer uma das partes. Pelo contrário. A sua proteção apresenta-se devidamente fortalecida, quando a decisão operante da coisa julgada vivifica sem qualquer ataque a princípios maiores constitucionais e que se refletem na protefão da cidadania que com o seu trabalho sustenta, pela via dos tributos pagos, a máquina estatal" (STJ, la T., Resp. n. 240.712/SP, rel. Min. José Augusto Delgado, v.u., j. 15.2.00, DJU 24.4.00). "O Estado, em sua dimensão ética, não protege a sentença judicial, mesmo transitada em julgado, que bate de frente com os princípios da moralidade e da legalidade, que espelhe única e exclusivamente vontade pessoal do julgador e que vá de encontro à realidade dos fatos. A moralidade está insita em càda regra posta na Constituição e em qualyuer mensagem de cunho ordinário ou regulamentar. Ele é comando com forfa maior e de cunho imperativo, reinando de modo absoluto sobre qualquer outro princípio, até mesmo sobre o da coisa julgada" (JOSÉ AUGUSTO DELGADO, Pontos polêmicos das ą̧öes de indenizaçāo de áreas naturais protegidas - efeitos da coisa julgada e os princípios constitucionais, p. 11). Cfr., ainda, CÂNDIDO RANGEl DinamarCo, Relativizar a coisa julgada material, p. 21; HUMBERTo THEODORo JÚNIOR, Embargos à execução contra a fazenda pública - extensão) da matéria argüivel - princípios constitucionais em conflito-proporcionalidade ou razoabilidade - coisa julgada e justa indenizaçāo - princípio de justiça e moralidade, pp. 133-135. Acerca da grande relevância constitucional do princípio da moralidade pública, cfr. SÉrgı FERraz, Aspectos processuais na lei sobre improbidade administrativa, pp. 364-365; CAIO TÁCITO, Moralidade administrativa, pp. 1-10. 
humana, ${ }^{78}$ do meio ambiente ecologicamente equilibrado, ${ }^{79}$ "do acesso à ordem jurídica justa, que repele a perenização de julgados aberrantemente discrepantes dos ditames da justiça e da equiidade ${ }^{80}$ do repúdio à fraude e ao erro grosseiro, ${ }^{81}$ entre outros princípios.

Questão de grande controvérsia na jurisprudência pátria diz respeito às ações de investigação de paternidade, propostas antes do advento dos modernos e precisos testes destinados a provar os laços familiares entre determinados indivíduos (DNA e HLA), cujas sentenças, acobertadas pela autoridade da coisa julgada material, não refletem as reais relações de parentesco. ${ }^{{ }^{2}}$

78. Cfr. Càndido Rangel Dinamarco, Relativizar a coisa julgada material, p. 21. Segundo José Afonso da Silva, "a eminência da dignidade da pessóa humana é tal que é dotada ao mesmo tempo da natureza de valor supremo, princípio constitucional fundamental e geral que inspira a ordem jurídica. Mas a verdade é que a Constituição lhe dá mais do que isso, quando a põe como fundamento da República Federativa do Brasil constituída em Estado Democrático de Direito. Se éfundamento é porque se constitui num valor supremo, num valor fundante da República, da Federação, do país, de democracia e do direito. Portanto, não é apenas um princípio da ordem jurídica, mas o é também da ordem política, social econômica e cultural. Daí sua natureza de valor supremo, porque está na base de toda a vida nacional" (Poder constituinte e poder popular - estudos sobre a Constituição, p. 147).

79. Cfr. Hugo Nigro Mazzilli, A defesa dos interesses difusos em juízo, pp. 171-172; Cândido Rangel Dinamarco, Relativizar a coisa julgada material, p. 21.

80. CÂndido Rangel Dinamarco, Relativizar a coisa julgada material, p. 21.

81. "Nunca há de ser admitido, cono culto constante à democracia e aos valores que ela apregoa, ser a coisa julgada utilizada para a prática de estelionatos pelas vias processuais, descomhecendo-se os princípios éticos presentes em qualquer tipo de relação" (José Augusto Delgado, Pontos polêmicos das ações de indenizą̧ăo de áreas naturais protegidas - efeitos da coisa julgada e os princípios constitucionais, p. 36). Cfr., ainda, Càndido Rangel Dinamarco, Relativizar a coisa julgada material, p. 21; Ángela Ester Ledesma, La revisión de la cosa juzgada irrita y el fraude procesal, pp. 465-482. No Tribunal de Justiça do Estado de São Paulo foi analisada demanda na qual figuravam no pólo ativo inúmeras pessoas, caracterizando um litisconsórcio multitudinário. Sem atentar para a ilegitimidade ativa de alguns dos litisconsortes, foi proferida sentença, transitada em julgado, concedendo o provimento jurisdicional a pessoas que não se enquadravam na situaçāo pressuposta para a procedência da demanda. No caso, atenuando o caráter absoluto conferido à coisa julgada material, os julgadores consideraram possível analisar a legitimidade ativa ad causam no seio do processo de execução, não-obstante o direito reconhecido na sentença de mérito transitada em julgado. Cfr. TJSP, $7^{\text {a }}$ Câm. de Direito Público, AI n. 52.139.5/8, rel. Des. Sérgio Pıtombo, v.m., j. 15.12.97, in Bol. AASP 2059 (1998), p. 603-j.

82. Eis os termos de interessante caso narrado por Eduardo Juan Couture: "un hombre de sólida fortuna, propietario rural, habia tenido un hijo natural como fruto de sus relaciones íntimas com una persona de su servicio. Procurando hacer desaparecer las consecuencias jurídicas y económicas de aquel hecho, logró que la madre del menor diera mandato a una persona de confianza del padre, la que aceptó la consigna de promover un juicio de investigación de la paternidad contra el padre. Bajo la dirección, no aparente, de la misma persona, el padre compareció a defenderse, negando la verdad de los hechos relatados en la demanda. Abierto el juicio a prueba, el apoderado de la madre do dejó transcurrir deliberadamente sin producir prueba alguna. La sentencia, forzosamente, rechazó la demanda de investigación de la paternidad. Muchos años después, llegado el hijo a la mayoría de edad, promovió 
Escudadas em pronunciamento do Superior Tribunal de Justiça sobre o tema, mediante a concepção de que "seria terrificante para o exercício da jurisdição que fosse abandonada a regra absoluta da coisa julgada" ${ }^{3}$ grande parte da jurisprudência não vinha admitindo a revisão dessas sentenças após passado o prazo para a propositura de ação rescisória. ${ }^{84}$

Diante das premissas expostas nesse estudo, parece não ser essa a solução mais apropriada. Tal entendimento não se coaduna com a promessa constitucional do acesso à ordem jurídica justa e muito menos com os princípios informadores da família, e da dignidade da pessoa humana (Constituição Federal, art. $1^{\circ}$ inc. III e arts. 226 a 230). Até pouco tempo atrás, foram poucos os julgados que desconsideraram a coisa julgada nessa hipótese, destacando-se manifestação do Tribunal de Justiça do Distrito Federal na qual restou consignado que "a segurança jurídica cede ante valores mais altos, seja o de ofilho saber quem é seu pai, seja o de que os registros públicos devem espelhar a verdade real" e, concluindo, "a lei não poder tirar o direito de a pessoa saber se realmente a outra é seu ancestral", 85

demanda de investigación de la paternidad contra su padre u contra ella se opuso la excepción de cosa juzgada" (Revocación de los actos procesales fraudulentos, p. 388). Em uma situação como essa, passado o prazo para a propositura de ação rescisória, poderia o Poder Judiciário ignorar a verdade, a justiça, e esconder-se sob o manto da coisa julgada? Os escopos da jurisdição respondem negativamente à questão.

83. STJ, $3^{\text {a }}$ T., Resp n. 107.248/SP, rel. Min. Carlos Alberto Menezes Direito, v.u., j. 7.5.98, in Revista do Superior Tribunal de Justiça (1999), p. 217.

84. Cfr., nesse sentido, TJSC, Iª Câm. Cível, Ap. n. 99.017063-2, rel. Des. N. Trisoto, v.u., j. 28.3.00; TJRS, 7ª̂m. Cível, Al n. 70000218313, rel. Des. J. C. Teixeira Giorgis, j. 10.11.99; TJRS, $8^{\mathrm{a}}$ Câm. Cível, Al n. 597185123, rel. Des. A. C. Stangler Pereira, j. 11.12.97.

85. TJDF, I’ T., Ag. n. 19980020024464, rel. Des. VAlTER XAVIER, v.m., j. 12.4.99, DJU 30.6.99, p. 33. Cfr., no mesmo sentido, TJDF, $1^{\mathrm{a}} \mathrm{T}$., AC n. 46.600, rel. Des. Valter XAVIER, DJU 22.4 .98 , in

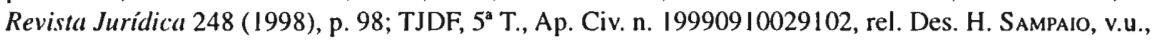
j. 14.9:00, DJU 22.11.00, p. 42. Acerca da possibilidade de revisão da coisa julgada em decorrência da evolução de técnicas científicas, cfr. ÓsCar A. Zorzolı, Cosa juzgada - mutabilidad, pp. 154-155. Discorrendo sobre o tema, R. Pereira e Silva considera conveniente, nas ações de estado, que a coisa julgada opere secundum eventum litis, não ocortendo sua incidência quando a sentença for desfavorável aos interesses da filiação. Cfr. O exame de DNA e a sua influência na investigação da paternidade biológica, pp. 79-80. Com solução um pouco diversa mas na mesma linha, Belmiro Pedro Welter aduz somente ocorrer "coisa julgada material na ação de investigaşão de paternidade quando produzidas todas as provas, documental, testemunhal e pericial, tendo em vista esse superdireito natural, constitucional $e$ indisponivel de personalidade, "qual, segundo já nos manifestamos, é inegociável, imprescritivel, impenhorável, personalissimo, indeclinável, absoluto, vitalício, indispensável, oponivel contra todos, intransmissivel, constituido de manifesto interesse público e essencial ao ser humano" (Coisa julgada na investigação de paternidade, pp. 23-24). Como já exposto anteriormente neste estudo, nessas hipóteses a coisa julgada opera normalınente. A proposta é de relativização da coisa julgada e não de delimitação dos efeitos sobre os quais ela incide. Desde que a sentença seja proferida com predisposição a produzir efeitos substanciais, afora os casos expressamente previstos em lei de incidência secundum eventum litis da coisa 
Essa inovadora orientação da jurisprudência foi recentemente acolhida no Superior Tribunal de Justiça, em julgado do qual foi relator o ministro Sálvio de Figueiredo Teixeira: "não excluida expressamente a paternidade do investigado na primitiva ação de investigação de paternidade, diante da precariedade da prova e da ausência de indícios suficientes a caracterizar tanto a paternidade como a sua negativa, e considerando que, quando do ajuizamento da primeira ação, o exame pelo DNA ainda não era disponível e nem havia notoriedade a seu respeito, admitese o ajuizamento de ação investigatória, ainda que tenha sido aforada uma anterior com sentença julgando improcedente o pedido... A coisa julgada, em se tratando de ações de estado, como no caso de investigação de paternidade, deve ser interpretada modus in rebus. Nas palavras de respeitável e avançada doutrina, quando estudiosos hoje se aprofundam no reestudo do instituto, na busca sobretudo da realização do processo justo, 'a coisa julgada existe como criação necessária à segurança prática das relações jurídicas e as dificuldades que se opõem à sua ruptura se explicam pela mesmíssima razão. Não se pode olvidar, todavia, que numa sociedade de homens livres, a Justiça tem de estar acima da segurança, porque sem justiça não há liberdade,",

Como já exposto anteriormente, o processo, seus institutos, são instrumentos voltados à efetivação do direito material, ao acesso à ordem jurídica justa, à pacificação social com Justiça. A coisa julgada não pode acobertar o engodo, a mentira, a fraude, não pode transformar a mentira em verdade. ${ }^{87}$ Nas palavras de

julgada, esse instituto opera normalmente. No entanto, diante da colisão entre a coisa julgada formada e outros princípios e garantias fundamentais, sua eficácia pode ser tolhida, prevalecendo uma solução diversa. De outra parte, não é conveniente e consentâneo com os princípios informadores do ordenamento jurídico pátrio que, nas ações de estado, a coisa julgada apenas incida quando a sentença for favorável àquele que pleiteia o reconhecimento da condição de filho. É também de grande relevância o interesse do suposto pai, na hipótese de sentença que de modo errôneo o declare pai, em desvincular-se da pessoa que comprovadamente não é seu filho.

86. STJ, 4a T., Resp n. 226.436/PR, rel. Min. SÁlvio de Figueiredo Teixeira, v.4., j. 28.6.01, in Revistı do Superior Tribunal de Justiça (2002), p. 403.

87. "A sentença não pode expressar comando acima das regras postas na Constituiçäo nem violentar os caminhos da natureza, por exemplo, determinando que alguém seja filho de outrem, quando a ciência demonstra que não o é. Será que a sentença, mesmo transitada em julgado, tem valor maior que a regra científica?' É dado ao juiz esse 'poder' absoluto de contrariar a própria ciência?' A resposta, com certeza é de cunho negativo. A sentença transitada em julgado, em época alguma, pode, por exemplo, ser considerada definitiva e produtora de efeitos concretos, quando determinar, com base exclusivamente em provas testemunhais e documentais, que alguém é filho de determinada pessoa e. posteriormente, em exame de DNA comprove o comtrário" (José Augusto Delgado, Pontos poilêmicos das açöes de indenizaçāo de áreas naturais protegidas - efeitos da coisa julgada e os principios constitucionais, p. 21). 
Cândido Rangel Dinamarco, o jurista nunca convenceria o uomo della strada, ${ }^{88}$ "de que o não-pai deva figurar como pai no registro civil, só porque ao tempo da ação de investigação de paternidade que lhe foi movida, inexistiam os testes imunológicos de hoje e o juiz decidiu com base na prova testemunhal. Nem o contrário: não convenceriamos o homem da rua de que o filho deva ficar privado de ter um pai, porque ao tempo da ação movida inexistiam aquelas provas e a demanda foi julgada improcedente, passando inexoravelmente em julgado" "

Outra questão de grande relevância prática diz respeito ao conflito entre a coisa julgada e a garantia constitucional da justa indenização. ${ }^{90}$

Em recente acórdão do Tribunal de Justiça do Estado de São Paulo restou consignada de forma expressa a prevalência da garantia da justa indenização perante a coisa julgada. O desembargador Sérgio Pitombo, revisor nessa oportunidade, após analisar extensamente a questão da oposição entre a coisa julgada e outros princípios constitucionais de maior grandeza, teceu esta conclusão: “o ato decisório definitivo, não mais sujeito a recurso, que exiba injustiça enorme - absurdos, fraudes, inconstitucionalidades e outras desfunções manifestas -, faz coisa julgada, tão só, de autoridade relativa - coisa julgada formal; preclusão máxima-. O valor Justiça não se há de abandonar, em prol da certeza e da segurança, com esquecimento da liberdade jurídica. A aludida derrelição implica perigoso afastamento de necessária crítica da razão prática" ${ }^{91}$

Sem qualquer pretensão de esgotar as hipóteses em que a coisa julgada deva ser relativizada, esses são alguns princípios e situações, dentre outros fundamentais,

88. "O homem simples, ingênuo e destituído de conhecimentos jurídicos, mas capaz de distinguir entre o bem e o mal, o sensato e o insensato, o justo e o injusto, segundo a imagem criada por Piero Calamandrei" (CÂndido Rangel. Dinamarco, Relativizar a coisa julgada material, p. 28).

89. Cândido Rangel Dinamarco, Relativizar a coisa julgada material, p. 28.

90. Nas palavras de Celso Antônio Bandeira de Mello, a justa indenização prevista no art. $5^{\circ}$, inc. XXIV, da Constituição Federal, "é aquela que corresponde real e efetivamente ao valor do bem expropriado, ou seja, aquela cuja importância deixe o expropriadó absolutamente indene, sem prejuízo algum em seu patrimônio. Indenização justa é a que se consubstancia em importância que habilita o propriefário a adquirir outro bem perfeitamente equivalente e o exime de qualquer detrimento" (Curso de direito administrativo, p. 538).

91. TJSP, $7^{\mathbf{a}}$ Câm. de Direito Público, Ap. n. 058.377-5/7, rel. Des. Torres de Carvalho, v. u., j. 26.3.01. Cfr., ainda, Humberto TheOdoro JúNIOR, Embargos à execução contra a fazenda pública extensāo da matéria argüível-princípios constitucionais em conflito-proporcionalidade ou razoabilidade - coisa julgada e justa indenização - princípio de justiça e moralidade, pp. 133-135; CÂNDIDo RANGEL DinAmarCo, Relativizar a coisa julgada material, pp. 25-27; LAERTE NORDL, Das indenizações ambientais milionairias, p. 108; STF, I’ T., Rext. n. 93.4I2/SC, rel. Min. RafaEL MAYER, v.m., j. 4.5.82; STF, I“ T., Rext. n. 105.012/RN, rel. Min. Neri da Silveira, v.m., j. 9.2.88; STJ, 6 T., Resp. n. 35.105-8/RJ, rel. Min. Luis Vicente Cernicchiaro, v.u., j. 31.5.93, DJU 28.6.93-b. 
que merecem especial atenção do jurista, mesmo quando diante de sentença transitada em julgado.

Na prática processual, em ocorrendo violação a princípio fundamental pela coisa julgada, passado o prazo para propositura de ação rescisória, é cabível demanda declaratória cujo objeto será a declaração de que a coisa julgada não prevalece, a declaração de sua ineficácia, ou então a propositura de demanda com outro objeto e pedido incidenter tantum de declaração da ineficácia da coisa julgada.

\section{Conclusão.}

Ao concluir este estudo, é necessário realizar uma importante ressalva a tudo o que foi dito. A solução alvitrada é excepcional, extraordinária, cabível somente em situações teratológicas, nas quais realmente não faça sentido e seja de extrema inconveniência à sociedade o respeito à coisa julgada. ${ }^{92}$

$\mathrm{Na}$ ponderação com outros princípios e garantias que informam o ordenamento jurídico pátrio, a segurança das decisões judiciais, consubstanciada na coisa julgada, dificilmente irá ser posta de lado ou ter sua influência demasiadamente reduzida. Como regra geral, a coisa julgada é um importante instrumento para o alcance dos escopos processuais, em especial o escopo maior, a pacificação social com Justiça.

No entanto, caso ocorra uma situação excepcional, na qual princípios e garantias fundamentais de nosso ordenamento jurídico sejam frontal e seriamente violados, perdendo todo e qualquer sentido o respeito à auctoritas rei judicatce, a coisa julgada deve ser relativizada, não podendo o Poder Judiciário acomodar-se sob o seu manto.

São Paulo, março de 2003.

92. No mesmo sentido as considerações de Cândido Rangel Dinamarco, ao concluir seu estudo sobre o tema: "a linha proposta não vai ao ponto insensato de minar imprudentemente a auctoritas rei judicata ou transgredir sistematicamente o que a seu respeito assegura a Constituição Federal e dispõe a lei. Propõe-se apenas um trato extraordinário destinado a situações extraordinárias com o objetivo de afastar absurdos, injustiças flagrantes, fraudes e infrą̧ões à Constituição - com a consciência de que providências destinadas a esse objetivo devem ser tão excepcionais quanto é a ocorrência desses graves inconvenientes. Não me move o intuito de propor uma insensata inversão, para que a garantia da coisa julgada passasse a operar em casos raros e a sua infringência se tornasse regra geral" (Relativizar a coisa julgada material, pp. 31-32). Uma disciplina demasiadamente flexível da questão poderia dar azo a repetição dos abusos ocorridos na Alemanha nazista. Nessa oportunidade, em 15 de julho de 1941 , foi promulgada lei concedendo ao Procurador-Geral do Reich, com o claro propósito de conformar as decisões do Poder Judiciário com os ideais nazistas, a faculdade de requerer a revisão, no prazo de um ano, de todas as decisões transitadas em julgado, caso existam "graves dúvidas fáticas ou jurídicas contra a correçāo da decisão e considerada necessária a renovação do processo em razão do seu significado especial para comunidade popular" (GuSTAV BOEHMER, Grundlagen der bürgelichen Rechtsordnung, v. I, pp. 98-99). 
Bibliografia

AleXY, Robert. trad. port. de Luís Afonso Heck, Colisão de direitos fundamentais e realização de direitos fundamentais no estado de direito democrático, in Revista de direito administrativo 217 (1999), pp. 67-79.

AsCEnsão, José de Oliveira. O direito - introdução e teoria geral - uma perspectiva luso-brasileira, Rio de Janeiro, Renovar, 1994.

BACHOF, Otto. Verfassungswidrige Verfassungsnormem?: 1951, trad. port. de José Manoel M. Cardoso da Costa, Normas constitucionais inconstitucionais?, Coimbra, Almedina, 1994.

Bandeira de Mello, Celso Antônio. Curso de direito administrativo, $9^{\mathrm{a}}$ ed., São Paulo, Malheiros, 1997.

Barbosa, Rui. Oração aos moços, in Discursos, orações e conferências, $4^{\mathrm{a}}$ ed., São Paulo, Edigraf, 1972.

Barbosa Moreira, José Carlos. A Constituição e as provas ilicitamente obtidas, in Temas de direito processual, 6 $6^{\mathbf{a}}$ Série, São Paulo, Saraiva, 1997, pp. 107-123.

- Ainda e sempre a coisa julgada, in Direito processual civil - Ensaios e pareceres, Rio de Janeiro, Borsói, 1971, pp. 133-146.

- A Justiça e nós, in Temas de direito processual, $6^{\text {a }}$ série, São Paulo, Saraiva, 1997, pp. 1-16.

O juiz e a cultura da transgressão, in Temas de direito processual, $7^{\mathrm{a}}$ série, São Paulo, Saraiva, 2001.

Regras de experiência e conceitos juridicamente indeterminados, in Estudos jurídicos em homenagem ao professor Orlando Gomes, Rio de Janeiro, Forense, 1979, pp. 605-622.

Bastos, Celso - Martins, Ives Gandra da Silva. Comentários à Constituição do Brasil, v.II, São Paulo, Saraiva, 1989.

- As modernas formas de interpretação constitucional, in Cadernos de direito constitucional e ciência política 24 (1998), pp. 45-50.

Beavin, Janet Helmick Watzlawick, Paul Jackson, Don. D.. Pragmatics of human communication -A study of interactional patterns, pathologies, and paradoxes, 1967, trad. port. de Álvaro Cabral, Pragmática da comunicação humana - Um estudo dos padrões, patologias e paradoxos da interação, São Paulo, Cultrix, s.a..

Bedaque, José Roberto dos Santos. Direito e processo - influência do direito material sobre o processo, $2^{\mathrm{a}}$ ed., São Paulo, Malheiros, 2001.

Discricionariedade judicial, in Revista Forense 354 (2001), pp. 187-195.

BoEHMER, Gustav. Grundlagen der bürgelichen Rechtsordnung, v. I, 1950, apud Carlos Alberto Álvaro de Oliveira, Do formalismo no processo civil, São Paulo, Saraiva, 1997. 
Bonavides, Paulo. Curso de direito constitucional, $8^{\mathrm{a}}$ ed., São Paulo, Malheiros, 1999.

CANARIS, Claus-Wilhelm. Systemdenken und Systembegriff in der Jurisprudenz, 1983, trad. port. de A. Menezes de Cordeiro, Pensamento sistemático e conceito de sistema na ciência do direito, $2^{\mathrm{a}}$ ed., Lisboa, Calouste Gulbenkian, 1996.

Carvalho, Paulo de Barros. Curso de direito tributário, $13^{\mathrm{a}}$ ed., São Paulo, Saraiva, 2000.

ChIovenda, Giuseppe. Istituzioni di diritto processuale civile, s. a., trad. port. de J. Guimarães Menegale, Instituições de direito processual civil, $3^{\mathbf{a}}$ ed., São Paulo, Saraiva, 1969.

- Sulla cosa giudicata, in Saggi di diritto processuale civile, v. 2, Milano, Giuffrè, 1993, pp. 399-409.

Cintra, Antônio Carlos de Araújo - Grinover, Ada Pelegrini - Dinamarco, Cândido Rangel. Teoria geral do processo, $15^{\mathrm{a}}$ ed., São Paulo, Malheiros, 1999.

Comoglo, Luigi Paolo. Garanzie costituzionali e 'giusto processo' - modelli a confronto, in Revista de processo 90 (1998), pp. 95-150.

Comparato, Fábio Konder. A afirmação histórica dos direitos humanos, São Paulo, Saraiva, 1999.

Couture, Eduardo Juan. Fundamentos del derecho procesal civil, $3^{\mathrm{a}}$ ed., Buenos Aires, Depalma, 1997.

Introdución al estudio del derecho procesal civil, s. a., trad. port. de Mozart Victor Russomano, Introdução ao estudo do processo civil, $3^{\text {a }}$ ed., Rio de Janeiro, Forense, 1998.

- Revocación de los actos procesales fraudulentos, in Estudios de derecho procesal civil, t. III, $2^{\mathrm{a}}$ ed., Buenos Aires, Depalma, 1978.

Delgado, José Augusto. Pontos polêmicos das ações de indenização de áreas naturais protegidas - efeitos da coisa julgada e os princípios constitucionais, in Revista de processo 103 (2001), pp. 9-36.

DiAs, Francisco Barros. Breve análise sobre a coisa julgada inconstitucional, in Revista dos Tribunais 758 (1998), pp.34-42.

Dinamarco, Cândido Rangel - Grinover, Ada Pelegrini -Cintra, Antônio Carlos de Araújo, Teoria geral do processo, $15^{\mathrm{a}}$ ed., São Paulo, Malheiros, 1999.

- A instrumentalidade do processo, $7^{\mathrm{a}}$ ed., São Paulo, Malheiros, 1999.

Aceleração dos procedimentos, in Fundamentos do processo civil moderno, $4^{\text {a }}$ ed., São Paulo, Malheiros, 2001.

Instituições de direito processual civil, v. I e III, São Paulo, Malheiros, 2001. Intervenção de terceiros, São Paulo, Malheiros, 1997.

- Relativizar a coisa julgada material, in Revista forense 358 (2001), pp. 11-32. Súmulas vinculantes, in Revista Forense 347 (1999), pp. 51-65. 
- Superior Tribunal de Justiça e acesso à ordem jurídica justa, in Sálvio de Figueiredo Teixeira (org.), Recursos no Superior Tribunal de Justiça, São Paulo, Saraiva, 1991, pp. 249-258.

ENGISCH, Karl. Einführung in das Juristische Denken, 1983, trad. port. de J. Baptista Machado, Introdução ao pensamento jurídico, $8^{\mathrm{a}}$ ed., Lisboa, Calouste Gulbenkian, 2001.

FERRAZ JÚNIOR, Tércio Sampaio. Estudos de filosofia do direito - reflexões sobre o poder, a liberdade, a justiça e o direito, São Paulo, Atlas, 2002.

- Introdução ao estudo do direito: técnica, decisão, dominação, $2^{\mathbf{a}}$ ed., São Paulo, Atlas, 1994.

- Justiça como retribuição - da razão e da emoção na construção do conceito de justiça, in Revista brasileira de filosofia XLIV (1998), pp. 369-389.

Teoria da norma jurídica: ensaio de pragmática da comunicação normativa, $3^{\mathrm{a}}$ ed., Rio de Janeiro, Forense, 1997.

FERRAZ, Sérgio. Aspectos processuais na lei sobre improbidade administrativa, in Cassio Scarpinella Bueno - Pedro Paulo de Rezende Porto Filho (org.), Improbidade administrativa - questões polêmicas e atuais, São Paulo, Malheiros, 2001, pp. 364-365.

GraU, Eros. O direito posto e o direito pressuposto, $3^{\mathrm{a}}$ ed., São Paulo, Malheiros, 2000.

Grinover, Ada Pelegrini - Cintra, Antônio Carlos de Araújo - Dinamarco, Cândido Rangel. Teoria geral do processo, 15a ed., São Paulo, Malheiros, 1999.

GUERRA FILHo, Willis Santiago. Reflexões a respeito da natureza da coisa julgada como problema filosófico, in Revista de processo 58 (1990), pp. 244-249

HABSCHEID, Walter J.. trad. port. de Arruda Alvim, As bases do direito processual civil, in Revista de processo 11-12 (1978), pp. 117-145.

HART, Herbert Lionel Adolphus. The concept of law, 1961, trad. port. de A. Ribeiro Mendes, $O$ conceito de direito, $2^{\mathrm{a}}$ ed., Lisboa, Calouste Gulbenkian, 1996.

HESSE, Konrad. Die normative Kraft der Verfassung, s.a., trad. port. de Gilmar Ferreira Mendes, A força normativa da constituição, Porto Alegre, Fabris, 1991.

JACkSON, Don. D. Watzlawick, Paul - Beavin, Janet Helmick. Pragmatics of human communication - A study of interactional patterns, pathologies, and paradoxes, 1967, trad. port. de Álvaro Cabral, Pragmática da comunicação humana - Um estudo dos padrões, patologias e paradoxos da interação, São Paulo, Cultrix, s.a..

KelSEN, Hans. Reine Rechtslehre, 1960, trad. port. de J. Baptista Machado, Teoria pura do direito, $6^{2}$ ed., Coimbra, Armênio Amado, 1984.

- What is justice?, 1957, trad. port. de Luís Carlos Borges, O que é justiça? -A justiça, o direito e a política no espelho da ciência, $2^{\mathrm{a}}$ ed., São Paulo, Martins Fontes, 1998.

LACERDA, Galeno. O código e o formalismo processual, in Ajuris 28, pp. 7-14. 
LAFER, Celso. A reconstrução dos direitos humanos, São Paulo, Companhia das Letras, 1999.

LARENZ, Karl. Methodenlehre der Rechtswissenschaft, 1991, trad. port. de J. Lamego, Metodologia da ciência do direito, $3^{\mathrm{a}}$ ed., Lisboa, Calouste Gulbenkian, 1997.

LEDESMA, Ángela Ester. La revisión de la cosa juzgada írrita y el fraude procesal, in Revista peruana de derecho procesal II (1998), pp. 465-482.

Liebman, Enrico Tullio. Efficacia ed autorità della sentenza, 1962, trad. port. de Alfredo Buzaid - Benvindo Aires, Eficácia e autoridade da sentença e outros escritos sobre a coisa julgada, $2^{\mathrm{a}}$ ed., Rio de Janeiro, Forense, 1981.

Manuale di diritto processuale civile, v. I, 1983, trad. port. de Cândido Rangel Dinamarco, Manual de direito processual civil, v. I, $2^{\mathrm{a}}$ ed., Rio de Janeiro, Forense, 1986.

Lucon, Paulo Henrique dos Santos. Garantia do tratamento paritário das partes, in José Rogério Cruz e Tucci (org.), Garantias constitucionais, do processo civil, São Paulo, Revista dos Tribunais, pp. 91-131.

Devido processo legal substancial, obra inédita.

Luhmann, Niklas. Rechtssoziologie, v. I, 1972, trad. port. de Gustavo Bayer, Sociologia do direito, v. I, Rio de Janeiro, Tempo Brasileiro, 1983.

Machado, Hugo de Brito. Direito adquirido e coisa julgada como garantias constitucionais, in Revista dos Tribunais 714 (1995), pp. 19-26.

MARQues, José Frederico. Instituições de direito processual civil, v. V, $2^{\mathrm{a}}$ ed., Rio de Janeiro, Forense, 1963.

Martins, Ives Gandra da Silva - Bastos, Celso. Comentários à Constituição do Brasil, v. II, São Paulo, Saraiva, 1989.

Maximiliano, Carlos. Hermenêutica e aplicação do direito, $18^{a}$ ed., Rio de Janeiro, Forense, 1999.

MÁynEz, Eduardo García. Algunos aspectos de la doctrina kelseniana, México, Porrúa, 1978.

Mazzilul, Hugo Nigro. A defesa dos interesses difusos em juízo, $10^{2}$ ed., São Paulo, Saraiva, 1998.

MENDONÇA LıMA, Alcides de. O processo como garantia das instituições sociais, in Revista de processo 13 (1979), pp. 147-158.

NoRDI, Laerte. Das indenizações ambientais milionárias, in Revista dos tribunais 794 (2001), pp. 101-108.

PeReira e Silva, R.. O exame de DNA e a sua influência na investigação da paternidade biológica, in Revista dos tribunais 783 (2001), pp. 65-84.

RADBRUCH, Gustav. Rechtsphilosophie, s.a., trad. port. de L. Cabral de Moncada, Filosofia do direito, $6^{a}$ ed., Coimbra, Arménio Amado, 1977.

Reale, Miguel. Nova fase do direito moderno, 2a ed., São Paulo, Saraiva, 1998. 
Revogação e anulamento do ato administrativo, Rio de Janeiro, Forense, 1968. ReCASÉns SiChes, Luis. Estudios de filosofía del derecho, Barcelona, Bosch, 1936. Introducción al estudio del derecho, $12^{\text {a }}$ ed., México, Porrúa, 1997

- Nueva filosofía de la interpretación del derecho, $2^{a}$ ed., México, Porrúa, 1973.

Tratado general de filosofía del derecho, $9^{\mathbf{a}} \mathrm{ed} .$, México, Porrúa, 1986.

Ross, Alf. On law and justice, 1958, trad. esp. de Genaro R. Carrió, Sobre el derecho y la justicia, $2^{a}$ cd., Buenos Aires, Eudeba, 1997.

Sımpaio Dórıı, Antônio de. Os direitos do homem, São Paulo, Nacional, 1942.

Schnaid, David. A interpretação jurídica constitucional (e legal), in Revista dos Tribunais 733 (1996), pp. 24-52.

Sılva, José Afonso da. Poder constituinte e poder popular - estudos sobre a Constituição, São Paulo, Malheiros, 2000.

TÁcıto, Caio. Moralidade administrativa, in Revista de direito administrativo 218 (1999), pp. 1-10.

Tarurfo, Michelle. trad. port. de Cândido Rangel Dinamarco, Senso comum, experiência e ciência no raciocínio do juiz, in Revista Forense 355 (2001), pp. 101-118.

Telles Júnior, Goffiredo. A follaci dobrada, Rio de Janciro, Nova Fronteira, 1999.

THEOdORO JúNIOR, Humberto. Embargos à execução contra a fazenda públicaextensão da matéria argiível - princípios constitucionais em conflito proporcionalidade ou razoabilidade - coisa julgada e justa indenização - princípio de justiça e moralidade, in M. de Aquino - P. Ubiratan Escorel de Azevedo (org.), Regularização imobiliária de âreas protegidas, v. II, São Paulo, Procuradoria Geral do Estado de São Paulo, 1999, pp. 120-137.

VAMPRÉ, Spencer. Institutas do imperador Justiniano, São Paulo, s.e., 1915.

Vidigal, Luis Eulalio de Bueno. Da ação rescisória dos julgados, São Paulo, Saraiva, 1948.

Watanabe, Kasuo. Assistência judiciária e o juizado de pequenas causas, in Kasuo Watanabe (org.), Juizado especial de pequenas causas, São Paulo, Revista dos Tribunais, 1985.

Watzlawick, Paul- Beavin, Janet Helmick-Jackson, Don. D.. Pragmatics of human communication -A study of interactional patterns, pathologies, and paradoxes, 1967, trad. port. de Álvaro Cabral, Pragmática da comunicação humana - Um estudo dos padrões, patologias e paradoxos da interação, São Paulo, Cultrix, s.a..

WeIter, Belmiro Pedro. Coisa julgada na investigação de paternidade, in Revista Juridica 256 (1999), pp. 19-25.

Zorzolı, Óscar A.. Cosa juzgada-mutabilidad, in Revista peruana de derecho procesal, II (1998). 